\title{
Geochemical evolution of groundwater in the Mud Lake area, Eastern Idaho, USA
}

\author{
Gordon Rattray
}

Received: 19 June 2014/ Accepted: 22 December 2014/Published online: 10 January 2015

(C) The Author(s) 2015. This article is published with open access at Springerlink.com

\begin{abstract}
Groundwater with elevated dissolved-solids concentrations - containing large concentrations of chloride, sodium, sulfate, and calcium - is present in the Mud Lake area of Eastern Idaho. The source of these solutes is unknown; however, an understanding of the geochemical sources and processes controlling their presence in groundwater in the Mud Lake area is needed to better understand the geochemical sources and processes controlling the water quality of groundwater at the Idaho National Laboratory. The geochemical sources and processes controlling the water quality of groundwater in the Mud Lake area were determined by investigating the geology, hydrology, land use, and groundwater geochemistry in the Mud Lake area, proposing sources for solutes, and testing the proposed sources through geochemical modeling with PHREEQC. Modeling indicated that sources of water to the eastern Snake River Plain aquifer were groundwater from the Beaverhead Mountains and the Camas Creek drainage basin; surface water from Medicine Lodge and Camas Creeks, Mud Lake, and irrigation water; and upward flow of geothermal water from beneath the aquifer. Mixing of groundwater with surface water or other groundwater occurred throughout the aquifer. Carbonate reactions, silicate weathering, and dissolution of evaporite minerals and fertilizer explain most of the changes in chemistry in the aquifer. Redox reactions, cation exchange, and evaporation were locally important. The source of large concentrations of chloride, sodium, sulfate, and calcium was evaporite deposits in the unsaturated zone associated with Pleistocene Lake Terreton. Large amounts of chloride,
\end{abstract}

G. Rattray $(\bowtie)$

U.S. Geological Survey, 1955 Fremont, Idaho Falls,

ID 83415, USA

e-mail: grattray@usgs.gov sodium, sulfate, and calcium are added to groundwater from irrigation water infiltrating through lake bed sediments containing evaporite deposits and the resultant dissolution of gypsum, halite, sylvite, and bischofite.

Keywords Geochemistry - Evaporite deposits · Geochemical modeling · PHREEQC · Groundwater

\section{Introduction}

Groundwater in the Mud Lake (Fig. 1) area has elevated dissolved-solids concentrations, primarily from large concentrations of chloride, sodium, sulfate, and calcium (Stearns et al. 1939; Robertson et al. 1974; Spinazola et al. 1992; Ginsbach 2013). The source of the large concentrations of chloride, sodium, sulfate, and calcium is unknown (Olmstead 1962; Robertson et al. 1974), although proposed sources include solution of continuous fallout of $\mathrm{NaCl}$ from the atmosphere, evaporation, infiltration of irrigation water, leaching of $\mathrm{NaCl}$ from the soil horizon, solution of evaporite deposits, inputs of $\mathrm{HCl}$ and $\mathrm{H}_{2} \mathrm{SO}_{4}$, inflow of thermal water, flushing of grain boundaries and pores from marine sediments, dissolution of fluid inclusion $\mathrm{NaCl}$ from basalt, and water-rock interaction with rhyolite and andesite (Robertson et al. 1974; Wood and Low 1988; Schramke et al. 1996; Busenberg et al. 2001; Ginsbach 2013).

Groundwater in the Mud Lake area resides in the eastern Snake River Plain (ESRP) aquifer, a sole-source fracturedbasalt aquifer of significant economic value to the State of Idaho. Recharge to the Mud Lake area occurs from the Camas Creek and Medicine Lodge Creek drainage basins in the extreme northeastern extent of the aquifer, and groundwater in the aquifer flows downgradient (southwest) from the Mud Lake area through the Idaho National Laboratory 


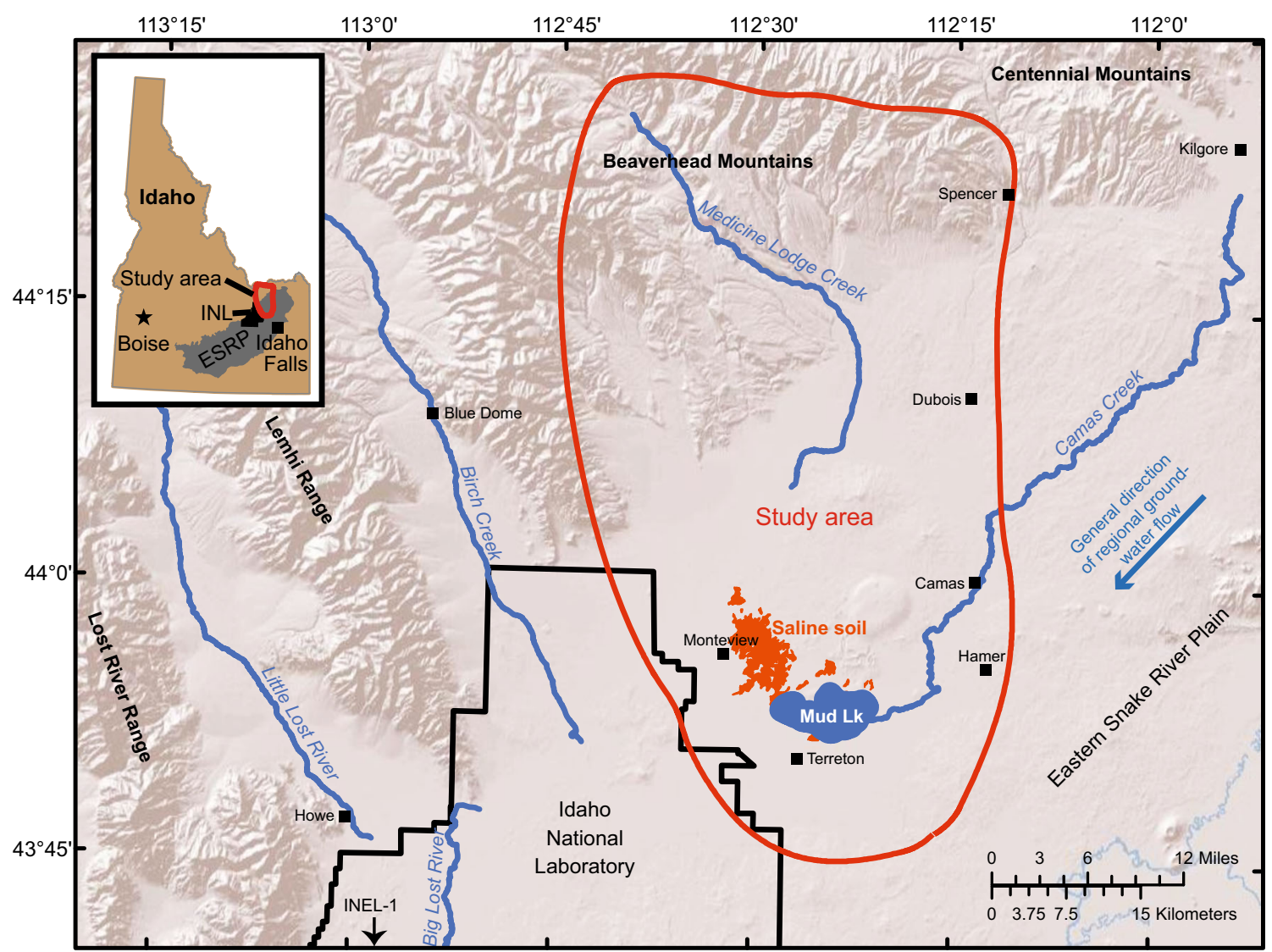

Fig. 1 Map showing study area, mountains, streams, eastern Snake River Plain (ESRP), Idaho National Laboratory (INL), saline soil (U.S. Department of Agriculture 2014), deep test well INEL-1, and general direction of regional groundwater flow

(INL). Consequently, the water quality of groundwater in the Mud Lake area influences the water quality of groundwater at the INL, and an understanding of the geochemical sources and processes controlling the water quality of groundwater in the Mud Lake area will provide a better understanding of the sources and processes controlling the water quality of groundwater at the INL, a long-term goal of the Department of Energy and the U.S. Geological Survey (Knobel et al. 2005). The geochemical sources and processes controlling the water quality of groundwater of the Mud Lake area were determined by investigating the geology, hydrology, land use, and groundwater geochemistry in the Mud Lake area, proposing sources for solutes, and testing the proposed sources through geochemical modeling with PHREEQC (Parkhurst and Appelo 2013).

\section{Study area}

The study area includes approximately $1,300 \mathrm{~km}^{2}$ of the Beaverhead Mountains and $1,650 \mathrm{~km}^{2}$ of the ESRP. Annual precipitation ranges from about $20 \mathrm{~cm}$ at Mud Lake to more than $150 \mathrm{~cm}$ in the mountains (Spinazola 1994). Land cover is primarily shrub and forest in the mountains and shrub and irrigated agriculture in the ESRP (Fig. 2).

Sedimentary rocks, rhyolite, and sediment are present in the mountains and rhyolite underlies basalt and sediment in the ESRP (Morgan et al. 1984; Kuntz et al. 1992; Ginsbach 2013) (Fig. 3). Volcanic rift zones (Kuntz et al. 1992) and vent corridors (Anderson et al. 1999) are linear features on the ESRP that contain centers of basalt eruptions. Sediment in the ESRP is present at the surface and interbedded with basalt flows in the subsurface. Surface and interbed sediments of lacustrine origin (Stearns et al. 1939; Nace et al. 1956; Kuntz et al. 1994; Lewis et al. 2012) reside within the Mud Lake subbasin (Fig. 3) and probably include evaporite deposits formed during the multiple climatederived fluctuations of Pleistocene Lake Terreton (Gianniny et al. 2002). Evidence of evaporite deposits in the Mud Lake area was provided from gypsum identified in sediments associated with Pleistocene Lake Terreton (Blair 2001; Geslin et al. 2002) and geochemical modeling of groundwater in the eastern part of the Mud Lake area (Rattray and Ginsbach 2014). Minerals in the study area include calcite and dolomite in sedimentary rocks; glass, quartz, potassium feldspar, plagioclase $\left(\mathrm{An}_{10-35}\right)$, and iron 
Fig. 2 Map showing land cover (U.S. Geological Survey 2007), Camas National Wildlife Refuge, Mud Lake Wildlife Management Area, irrigation canals, and highways

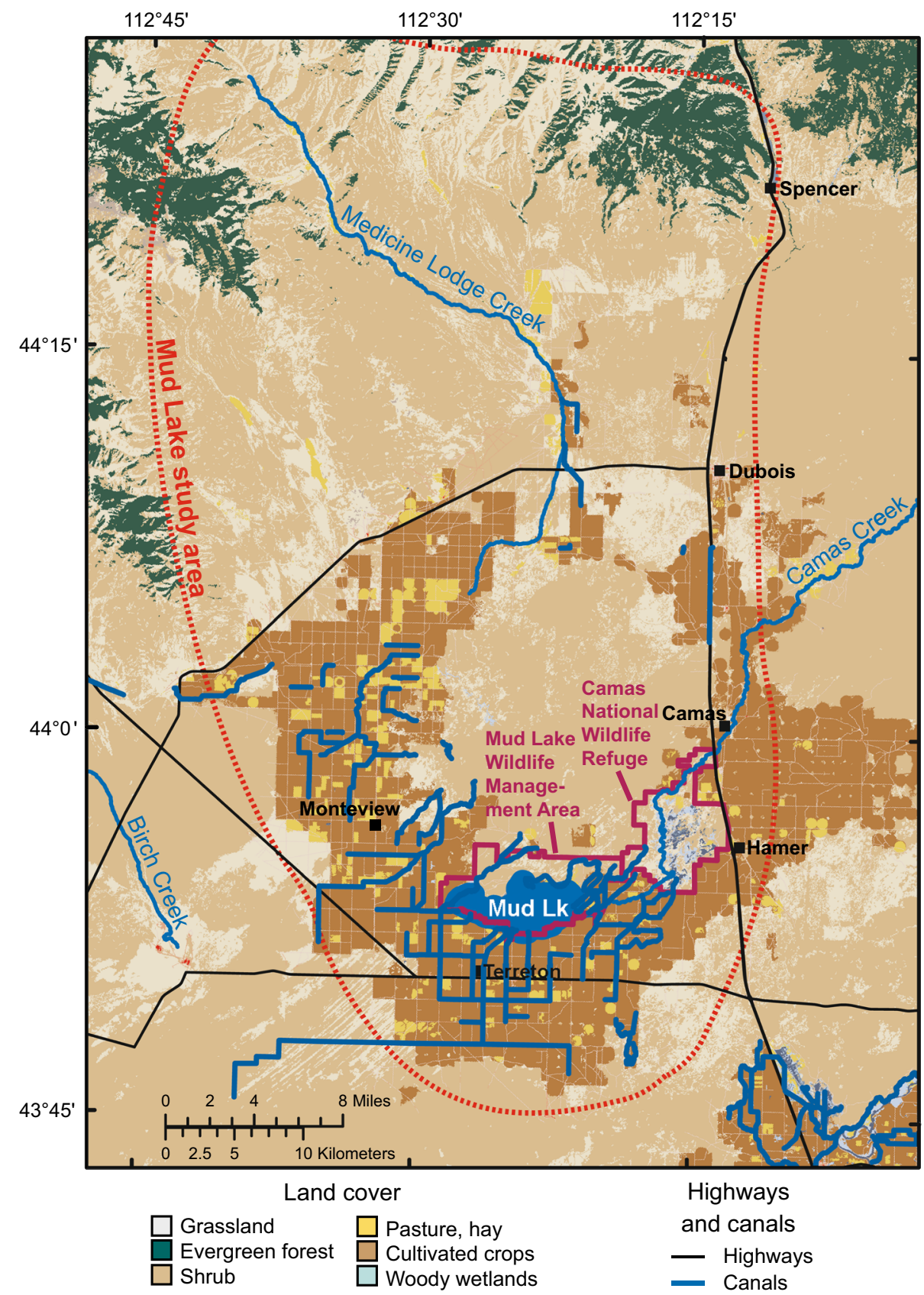

oxides in rhyolite; and glass, olivine, plagioclase $\left(\mathrm{An}_{50-70}\right)$, pyroxene, and iron oxides in basalt. All of these minerals plus sedimentary rock, rhyolite, and basalt fragments, evaporite minerals, and clay minerals (illite, kaolinite, and montmorillonite) are present in sediment on the ESRP (Ginsbach 2013; Rattray and Ginsbach 2014).

Surface water in the study area (Fig. 2) includes Medicine Lodge and Camas Creeks, both of which terminate on the ESRP; Mud Lake; ponds, lakes, and wetlands at the Camas National Wildlife Refuge (CNWR) and Mud Lake Wildlife Management Area; irrigation canals; and applied irrigation water. Camas Creek is the primary source of surface water to Mud Lake and for most surface water irrigation in the study area; pumped groundwater is also used for irrigation. Infiltration recharge from surface water occurs from Medicine Lodge and Camas Creeks; ponds, lakes, and wetlands at Mud Lake and the CNWR; irrigation canals; and excess irrigation water (Spinazola 1994).

The unsaturated zone in the ESRP ranges from a few meters at the CNWR to tens of meters elsewhere and includes a perched groundwater zone that extends south and west of Mud Lake (Stearns et al. 1939). The ESRP aquifer is comprised of hundreds of intercalated, subhorizontal layers of basalt and sediment (Lindholm 1996) and is 
Fig. 3 Map showing surface geology (Lewis et al. 2012), volcanic vent corridors (Anderson et al. 1999), and water-quality site locations and numbers

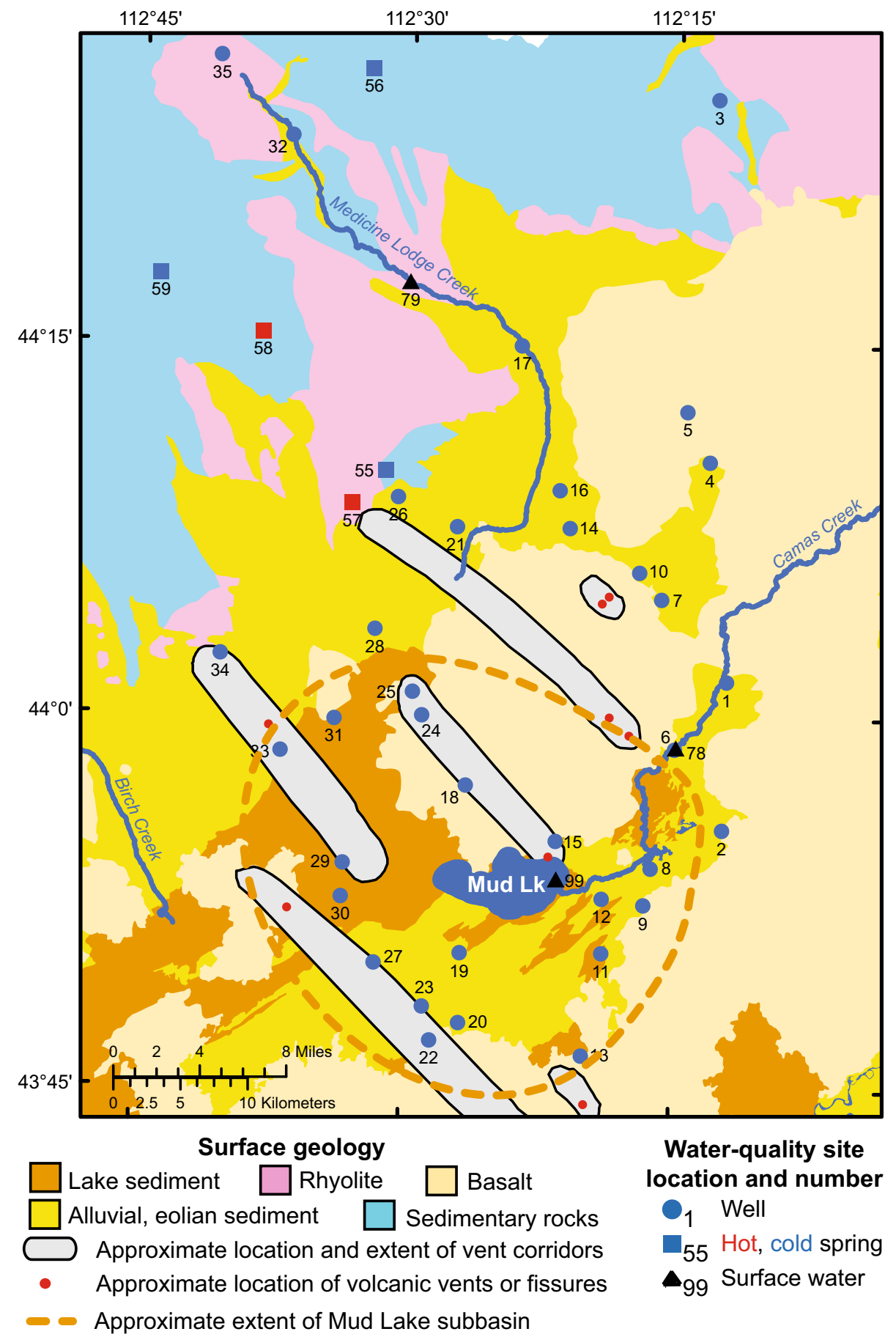

estimated to be $>1,000 \mathrm{~m}$ thick in some locations (Garabedian 1992). A clay layer creates confined aquifer conditions in the area around Mud Lake (Spinazola 1994), but the aquifer is unconfined elsewhere. Most groundwater flow in the aquifer is horizontal and occurs in rubble- and sedimentfilled interflow zones between basalt flows (Ackerman et al. 2006), although dikes associated with volcanic vent corridors may impede horizontal flow (Anderson et al. 1999). Downward groundwater movement occurs near the margins of the ESRP and southwest of Mud Lake, and upward movement occurs in parts of Camas Creek, Mud Lake, the CNWR (Spinazola 1994), and within vent corridors where fissures and dikes may facilitate upward circulation of geothermal water (Anderson et al. 1999).

Water-table contours indicate that groundwater flows into the ESRP aquifer from the Beaverhead Mountains and Camas Creek drainage basin and that groundwater generally flows south, southwest, or west (Fig. 4). Hydraulic gradients 
Fig. 4 Map showing watertable contours (in meters above the National Geodetic Vertical Datum of 1929), water-level measurement sites, generalized groundwater flow directions, and water-quality site locations and numbers

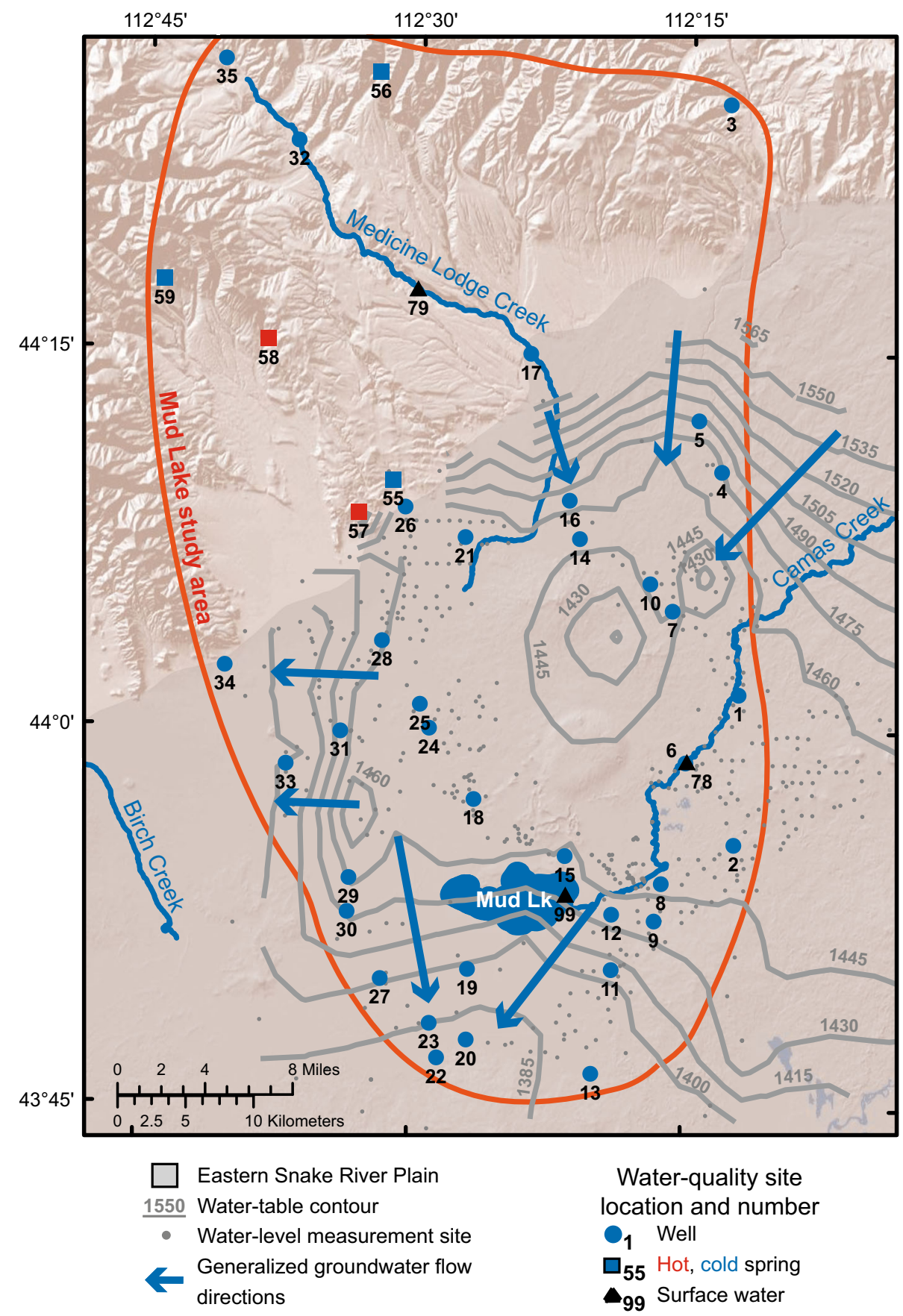

calculated from water-table contours are relatively flat north of Mud Lake (approximately $0.5 \mathrm{~m} / \mathrm{km}$ ) and relatively steep in the northern part of the ESRP and south of Mud Lake (approximately 9.5 and $5.7 \mathrm{~m} / \mathrm{km}$, respectively). These gradients are similar to those observed for the ESRP aquifer at and near the INL $(0.2-11 \mathrm{~m} / \mathrm{km})$, and given the similar aquifer materials and stratigraphy for the Mud Lake area and the INL, average linear flow velocities in the Mud Lake area are probably similar to the $0.6-6 \mathrm{~m} / \mathrm{d}$ velocities estimated at and near the INL (Ackerman et al. 2006).

\section{Water-quality sampling and analytical methods}

Water-quality samples were collected between 1979 and 2012 from 41 groundwater (36 wells and 5 springs) and three surface-water (two streams, one lake) sites (Table 1; Fig. 4). All of the springs and three of the wells are located in the Beaverhead Mountains; the remaining 33 well sites are located on the ESRP. Wells include 20 irrigation, 12 domestic, and 1 stock, recreation, monitoring, and deep (geothermal) test well. The depth to water in wells 
(excluding the 3,159-m deep test well INEL-1, site 100; Fig. 1) on the ESRP ranged from about 3-137 $\mathrm{m}$ with a mean depth of about $53 \mathrm{~m}$; the maximum depth of well open intervals was $71 \mathrm{~m}$ with a mean maximum depth of $33 \mathrm{~m}$. Consequently, this study investigates the geochemistry of the shallow (upper $71 \mathrm{~m}$ ) ESRP aquifer.

All water-quality samples, including three replicate samples (Ginsbach 2013; Rattray and Ginsbach 2014), were collected by the USGS following methods presented in the USGS National Field Manual for the Collection of Water-Quality Data (U.S. Geological Survey 2006), Rattray and Ginsbach (2014), Ginsbach (2013), Busenberg et al. (2000), and Knobel et al. (1999). Laboratory analytical methods and data-reporting conventions were presented in Rattray and Ginsbach (2014), Busenberg et al. (2000), and Knobel et al. (1999).

\section{Analytical results and quality assurance}

Analytical results are shown in Tables 1, 2, 3, and 4.

The reliability of water-quality data was evaluated with the replicate samples and calculation of the charge balance (CB) of water samples. Evaluation of the replicate samples followed procedures described in Rattray (2014), and all replicate results were acceptable except for one of the three results for both aluminum and iron (Rattray and Ginsbach 2014). CB errors of $5 \%$ or less generally are considered acceptable for analyses of water samples (Freeze and Cherry, 1979). Of the 44 water samples used in this report, 42 had absolute-value CB errors of $<4 \%, 1$ sample had a $\mathrm{CB}$ error of $-5.3 \%$ (site 22), and 1 sample had a CB error of $-14.4 \%$ (site 79 ; it is not clear why this sample had a high CB error; this sample and data were included in this report because it is the only sample from this site with a complete set of water-quality data) (Table 2).

\section{Geochemistry}

\section{Water chemistry}

Surface water has variable water temperature, dissolved oxygen (DO), and specific conductance (SpC) (Table 1) because of seasonal changes in air temperature, the dependence of oxygen solubility on water temperature, and evaporation. $\mathrm{pH}$ was 7.8 for Camas Creek, 8.0 for Medicine Lodge Creek, and 7.0 for Mud Lake. Nitrate concentrations were $\leq 0.25 \mathrm{mg} / \mathrm{L}$ as N (Table 3). Camas Creek had a tritium concentration of $26.6 \pm 2.1 \mathrm{pCi} / \mathrm{L}$ and a $\delta^{13} \mathrm{C}$ value of $-7.98 \%$ (Table 4 ).

Thermal springs in the mountains (Lidy Hot Spring and Warm Spring, sites 57 and 58) were hot ( 48.4 and $27.8^{\circ} \mathrm{C}$ ), had low pH (7.2 and 7.1), and had $\mathrm{SpC}$ of 694 and $430 \mu \mathrm{S} /$ $\mathrm{cm}$ at $25{ }^{\circ} \mathrm{C}$. Lidy Hot Spring had large concentrations of calcium $(87 \mathrm{mg} / \mathrm{L})$, potassium $(13.6 \mathrm{mg} / \mathrm{L})$, sulfate $(191 \mathrm{mg} / \mathrm{L})$, fluoride $(7.0 \mathrm{mg} / \mathrm{L})$, lithium $(48 \mu \mathrm{g} / \mathrm{L})$, and strontium $(1,000 \mu \mathrm{g} / \mathrm{L})$ and a measurable concentration of ammonia $(0.11 \mathrm{mg} / \mathrm{L}$ as $\mathrm{N}$ ) (Tables 2,3$)$. Warm Spring had much smaller concentrations of these chemical species than Lidy Hot Spring, but had higher concentrations of magnesium $(19.7 \mathrm{mg} / \mathrm{L})$ and bicarbonate $(198 \mathrm{mg} / \mathrm{L})$. Tritium concentrations were $0.4 \pm 0.3$ and $3.1 \pm 2.1 \mathrm{pCi} / \mathrm{L}$, and $\delta^{13} \mathrm{C}$ values were -3.9 and $-5.55 \%$. Deep geothermal water from the ESRP (site 100) was hot $\left(57^{\circ} \mathrm{C}\right.$ ), had a $\mathrm{pH}$ of 7.9 , was brackish $\left(2,870 \mu \mathrm{S} / \mathrm{cm}\right.$ at $\left.25^{\circ} \mathrm{C}\right)$, was presumed to be anoxic, and had small concentrations of calcium $(7.5 \mathrm{mg} / \mathrm{L})$ and magnesium $(0.5 \mathrm{mg} / \mathrm{L})$ and large concentrations of sodium $(390 \mathrm{mg} / \mathrm{L})$, bicarbonate $(900 \mathrm{mg} / \mathrm{L})$, sulfate $(99 \mathrm{mg} / \mathrm{L})$, fluoride $(13 \mathrm{mg} / \mathrm{L})$, boron $(560 \mu \mathrm{g} / \mathrm{L})$, and iron $(1,100 \mu \mathrm{g} / \mathrm{L})$.

Groundwater from wells (sites 3, 32, and 35) and cold springs (sites 55, 56, and 59) in the mountains had temperatures ranging from 5.8 to $12.8^{\circ} \mathrm{C}, \mathrm{pH}$ ranging from 6.9 to $7.8, \mathrm{SpC}$ ranging from 258 to $523 \mu \mathrm{S} / \mathrm{cm}$ at $25{ }^{\circ} \mathrm{C}$, were anoxic to slightly undersaturated with oxygen (1.1-94.4\% saturation), and had moderate-to-large carbon dioxide $\left(\mathrm{CO}_{2}\right)$ concentrations $\left(\log \mathrm{PCO}_{2}\right.$ of -2.61 to -1.58$)$ and nitrate concentrations of $\leq 0.88 \mathrm{mg} / \mathrm{L}$ as $\mathrm{N}$. Tritium concentrations ranged from $-0.5 \pm 1.9$ to $33.1 \pm 2.5 \mathrm{pCi} / \mathrm{L}$ and $\delta^{13} \mathrm{C}$ values ranged from -12.72 to $-8.18 \%$.

Groundwater from the ESRP aquifer (32 sites excluding site 100) exhibited a wide range in chemistry (Tables 1,2 , 3, 4). Temperature, $\mathrm{pH}$, and $\mathrm{SpC}$ ranged from 9.0 to $17.7{ }^{\circ} \mathrm{C}, 7.0$ to 8.5 , and 249 to $929 \mu \mathrm{S} / \mathrm{cm}$ at $25^{\circ} \mathrm{C}$, respectively. DO ranged from anoxic to supersaturated $(<2.3-122.5 \%$ saturation $)$ and $\log \mathrm{PCO}_{2}$ ranged from -3.25 to -1.72 . Cation and anion concentrations (in $\mathrm{mg} / \mathrm{L}$ ) ranged from 15 to 109 for calcium, 4.6 to 33.0 for magnesium, 9.0 to 85.0 for sodium, 2.0 to 7.2 for potassium, 131 to 457 for bicarbonate, 5.6 to 121 for chloride, 5.3 to 91.3 for sulfate, 0.15 to 1.01 for fluoride, and $<0.05$ to $13.2 \mathrm{mg} / \mathrm{L}$ as $\mathrm{N}$ for nitrate. Ammonia concentrations $>0.03 \mathrm{mg} / \mathrm{L}$ as $\mathrm{N}$ were measured in water from a few sites (sites 18, 25, 27, and 29), and large lithium concentrations were measured at sites $25(71 \mu \mathrm{g} / \mathrm{L})$ and $29(47 \mu \mathrm{g} / \mathrm{L})$. Tritium ranged from $-22 \pm 13$ to $96 \pm 13 \mathrm{pCi} / \mathrm{L}$ and $\delta^{13} \mathrm{C}$ values ranged from -15 to $-11.2 \%$. No trends in the spatial distribution of physical and chemical parameters were apparent, although larger $\mathrm{SpC}$ and ion concentrations were generally from groundwater in the southwestern part of the study area (Fig. 5).

The hydrochemical facies (Fig. 6) of water was calcium bicarbonate for surface water, most groundwater from the mountains, and 19 of 32 groundwater samples from the ESRP. The hydrochemical facies of other groundwater from the ESRP were various combinations of calcium-, 
Table 1 Site number, date sampled, measurements of field parameters, and calculated carbon dioxide concentration

\begin{tabular}{|c|c|c|c|c|c|c|c|}
\hline Report site no. & USGS site no. & $\begin{array}{l}\text { Date } \\
\text { sampled }\end{array}$ & $\begin{array}{l}\text { Temperature } \\
\left({ }^{\circ} \mathrm{C}\right)\end{array}$ & $\mathrm{pH}$ & $\begin{array}{l}\text { Specific conductance } \\
\left(\mu \mathrm{S} / \mathrm{cm} \text { at } 25^{\circ} \mathrm{C}\right)\end{array}$ & $\begin{array}{l}\text { Dissolved oxygen } \\
\text { (\% saturation) }\end{array}$ & $\begin{array}{l}\text { Carbon dioxide } \\
\left(\log \mathrm{PCO}_{2}\right)\end{array}$ \\
\hline 1 & 440127112120601 & $7 / 22 / 2010$ & 11.4 & 7.4 & 509 & 96.6 & -2.31 \\
\hline 2 & 435532112121401 & $7 / 30 / 2007$ & 13.2 & 7.7 & 311 & 82.2 & -2.58 \\
\hline 3 & 442456112125501 & $8 / 8 / 2011$ & 7.9 & 7.8 & 325 & 1.1 & -2.61 \\
\hline 4 & 441023112131201 & $7 / 3 / 2008$ & 13.9 & 7.9 & 284 & 104.7 & -2.82 \\
\hline 5 & 441222112142701 & $8 / 9 / 2011$ & 14.4 & 7.9 & 292 & 98.5 & -2.84 \\
\hline 6 & 435846112145601 & $8 / 8 / 2011$ & 12.1 & 8.3 & 249 & 89.6 & -3.25 \\
\hline 7 & 440451112154601 & $7 / 22 / 2010$ & 14.2 & 7.3 & 340 & 106.4 & -2.17 \\
\hline 8 & 435358112161101 & $7 / 20 / 2011$ & 10.6 & 7.0 & 431 & 25.2 & -1.72 \\
\hline 9 & 435229112163202 & $8 / 23 / 2011$ & 12.9 & 7.6 & 370 & $70^{\mathrm{a}}$ & -2.44 \\
\hline 10 & 440553112170001 & $7 / 12 / 2011$ & 15.5 & 8.0 & 278 & $92.6^{\mathrm{a}}$ & -2.89 \\
\hline 11 & 435031112182101 & $7 / 27 / 2010$ & 11.7 & 7.2 & 656 & 100.4 & -1.75 \\
\hline 12 & 435241112185201 & $8 / 9 / 2011$ & 12.8 & 7.8 & 301 & 54.3 & -2.66 \\
\hline 13 & 434624112194601 & $7 / 30 / 2008$ & 13.2 & 7.7 & 313 & 89.2 & -2.60 \\
\hline 14 & 440734112205401 & $7 / 12 / 2011$ & 12.6 & 7.9 & 417 & $95.8^{\mathrm{a}}$ & -2.77 \\
\hline 15 & 435500112212502 & $6 / 19 / 2007$ & 12.1 & 7.6 & 293 & 86.9 & -2.55 \\
\hline 16 & 440908112213501 & $7 / 3 / 2008$ & 13.6 & 7.9 & 452 & 97.0 & -2.58 \\
\hline 17 & 441456112234701 & $6 / 4 / 2012$ & 9.0 & 7.8 & 344 & 85.5 & -2.72 \\
\hline 18 & 435712112263201 & $9 / 23 / 2009$ & 13.2 & 7.9 & 265 & 108.5 & -2.80 \\
\hline 19 & 435028112264501 & $5 / 14 / 1997$ & 11.0 & 7.7 & $510^{\mathrm{b}}$ & $43^{c}$ & -2.33 \\
\hline 20 & 434739112264501 & $8 / 23 / 2011$ & 11.4 & 7.6 & 572 & $47.4^{\mathrm{a}}$ & -2.19 \\
\hline 21 & 440734112271401 & $7 / 3 / 2008$ & 11.0 & 7.5 & 560 & 103.2 & -2.17 \\
\hline 22 & 434657112282201 & $6 / 4 / 1991$ & 12.0 & 7.8 & 722 & 86.0 & -2.33 \\
\hline 23 & 434818112284801 & $8 / 29 / 1989$ & 14.6 & 7.9 & 613 & $47^{\mathrm{c}}$ & -2.63 \\
\hline 24 & 440001112290401 & $6 / 6 / 2012$ & 10.5 & 7.3 & 929 & 74.0 & -1.92 \\
\hline 25 & 440058112293605 & $6 / 11 / 1991$ & 12.5 & 8.1 & 282 & $<2.3$ & -2.99 \\
\hline 26 & 440847112303801 & $9 / 6 / 2006$ & 11.6 & 7.4 & 489 & 122.5 & -2.11 \\
\hline 27 & 435003112313101 & $6 / 26 / 2008$ & 17.7 & 8.2 & 307 & 42.8 & -3.09 \\
\hline 28 & 440328112314501 & $7 / 6 / 2006$ & 11.2 & 7.6 & 557 & 101.5 & -2.39 \\
\hline 29 & 435402112332101 & $6 / 12 / 1991$ & 12.5 & 8.5 & 335 & 7.9 & -3.32 \\
\hline 30 & 435241112332401 & $6 / 6 / 2012$ & 12.9 & 7.4 & 848 & 84.1 & -1.79 \\
\hline 31 & 435951112335701 & $6 / 6 / 2012$ & 11.2 & 7.3 & 692 & 49.2 & -1.93 \\
\hline 32 & 442317112364901 & $6 / 4 / 2012$ & 7.0 & 7.3 & 523 & 68.0 & -2.04 \\
\hline 33 & 435831112365401 & $8 / 30 / 2010$ & 12.4 & 7.2 & 823 & 105.2 & -2.00 \\
\hline 34 & 440226112402401 & $9 / 6 / 2006$ & 16.2 & 7.7 & 427 & 113.6 & -2.46 \\
\hline 35 & 442629112425601 & $6 / 4 / 2012$ & 10.7 & 7.4 & 400 & 76.1 & -2.22 \\
\hline 55 & 440951112311701 & $6 / 5 / 2012$ & 12.8 & 7.8 & 338 & 88.1 & -2.69 \\
\hline 56 & 442601112322201 & $6 / 5 / 2012$ & 5.8 & 6.9 & 360 & 89.4 & -1.58 \\
\hline 57 & 440832112331001 & $11 / 27 / 2000$ & 48.4 & 7.2 & 694 & $\approx 135$ & -1.82 \\
\hline 58 & 441522112381901 & $6 / 5 / 2012$ & 27.8 & 7.1 & 430 & 29.5 & -1.75 \\
\hline 59 & 441741112440701 & $6 / 5 / 2012$ & 7.3 & 7.4 & 258 & 94.4 & -2.36 \\
\hline 78 & 13114150 & $8 / 8 / 2011$ & 19.3 & 7.8 & 147 & 75.8 & -2.82 \\
\hline 79 & 13116000 & $10 / 3 / 1984$ & 7.8 & 8.0 & 470 & $105^{\mathrm{a}}$ & -2.62 \\
\hline 99 & 13115000 & $10 / 30 / 1984$ & 5.4 & $7.0^{\mathrm{b}}$ & 381 & $78.6^{\mathrm{a}}$ & -1.78 \\
\hline 100 & 433717112563501 & 6/1979 & 57 & 7.9 & $2,870^{\mathrm{b}}$ & $0^{\mathrm{c}}$ & -1.76 \\
\hline
\end{tabular}

Report site numbers 1-35 wells, 55-59 springs, 78-79 streams, 99 lake, 100 geothermal well

${ }^{a}$ Dissolved oxygen sample collected on different dates than indicated in Table

b Calculated with PHREEQC

${ }^{c}$ Estimated from hydrologic conditions at site and concentrations of dissolved oxygen in nearby groundwater 
sodium-, and magnesium-bicarbonates and calcium chloride bicarbonate (site 33). Thermal water was calcium sulfate (site 57), calcium bicarbonate (site 58), and sodium bicarbonate (site 100).

\section{Interpretation of isotopic data}

Most $\delta^{2} \mathrm{H}$ and $\delta^{18} \mathrm{O}$ values (Fig. 7) of groundwater in the study area (plus values for groundwater from the Centennial Mountains; these values are included in Fig. 7 because much of the groundwater in the study area originates from there) plot near and approximately parallel to the local meteoric water line for winter (Benjamin et al. 2004) indicating that most groundwater is of meteoric origin and from winter precipitation. All groundwater from the ESRP plots along a trend line (determined from linear regression of Mud Lake $\delta^{2} \mathrm{H}$ and $\delta^{18} \mathrm{O}$ values) for evaporation of Mud Lake water, but only sites 19, 22, and 23 (southwest of Mud Lake; Fig. 4) have large $\delta^{2} \mathrm{H}$ and $\delta^{18} \mathrm{O}$ values that indicate evaporated water was a significant source of recharge.

$\delta^{13} \mathrm{C}$ values in groundwater are influenced by the $\delta^{13} \mathrm{C}$ values of recharge water that equilibrates with unsaturated zone $\mathrm{CO}_{2}$ (with a $\delta^{13} \mathrm{C} \approx-24$ to $-30 \%$ ), fractionation of $\mathrm{CO}_{2}$ as $\mathrm{CO}_{2}$ gas in the unsaturated zone dissolves in groundwater $\left(\delta^{13} \mathrm{C}\right.$ in bicarbonate enriched by $\approx 9 \%$ ), dissolution of carbonates (carbonate $\delta^{13} \mathrm{C} \approx 0 \%$ ), and decay of organic matter (organic matter $\delta^{13} \mathrm{C} \approx-24$ to $-30 \%$ ) (Clark and Fritz 1997). The $\delta^{13} \mathrm{C}$ values measured from the mountains and the ESRP (Table 4) probably reflect a greater influence from dissolution of carbonates in the mountains and infiltrating surface water, decay of organic matter, or both in the ESRP.

The approximate age of water was estimated from tritium concentrations in water samples, monthly records (from 1953 to 2009) of tritium concentrations in precipitation (Michel 1989 and personal communication, International Atomic Energy Agency 2013), and the decay equation for tritium. Tritium concentrations indicating pre1952 (old), post-1952 (young), and a mixture of old and young water, for the years 1991 and 2012, are shown in Table 5. Old water was estimated for 2 sites in the mountains and 4 sites on the ESRP; young water was estimated for 3 sites in the mountains, 3 sites on the ESRP, and Camas Creek; and a mixture of young and old water was estimated for 3 sites in the mountains and 4 sites on the ESRP (Table 4). The old water on the ESRP was from sites (sites 5 and 17) in the northeastern part of the ESRP that received recharge from old water in the mountains (water similar in age to site 3, Table 4; Fig. 3) or from sites with unusual chemistry (i.e., anoxic water) located in volcanic vent corridors (sites 25 and 29). Groundwater from the other 7 sites on the ESRP was either young or a mixture of young and old water, indicating that a source of young water provided recharge to most of the shallow groundwater in the ESRP.

\section{Sources of solutes}

Solutes in groundwater are derived from recharge water, anthropogenic inputs, and chemical reactions. Potentially important sources of recharge water to the ESRP aquifer are groundwater from the Beaverhead Mountains, groundwater from the Camas Creek drainage basin (Rattray and Ginsbach 2014), infiltration of surface water (Medicine Lodge and Camas Creeks; lakes, ponds, and wetlands at Mud Lake and the CNWR; and irrigation water), and upwelling of geothermal water from beneath the aquifer (Mann 1986).

Upward movement of geothermal water occurs beneath the ESRP aquifer at the INL (site 100, Mann 1986) and may occur in the aquifer in the Mud Lake area within volcanic vent corridors (Anderson et al. 1999). Four sites (sites 25, 27, 29, and 34) located in volcanic vent corridors had either anoxic water $(<2.3$ and $7.9 \%$ saturation, Table 1) or high water temperatures $\left(16.2\right.$ and $17.7^{\circ} \mathrm{C}$, Table 1), which may indicate that geothermal water was a source of water to these sites. Other indicators of geothermal water were the presence of ammonia, elevated concentrations of fluoride, lithium, and boron (Tables 2,3), the large concentration ratio of sodium to total cations (in meq/L) for sites 25 and 27, consistent with mixing of geothermal water similar in chemical composition to site 100 with other water from the ESRP (Fig. 6), and hydraulic head measurements at and near site 25 that indicates upward flow of groundwater (U.S. Geological Survey 2014).

Anthropogenic inputs include fertilizer in irrigated areas and road salt and anti-icing liquid (beginning in 2000) on highways (Fig. 2). Fertilizer may be sources of nitrogen, potassium, and chloride; road salt and anti-icing liquid may be sources of sodium, magnesium, and chloride.

Potential chemical reactions include carbonate reactions, dissolution of evaporite minerals, silicate weathering, redox reactions, and cation exchange. Carbonate, evaporite, and silicate minerals are present throughout the study area. Carbonate and evaporite minerals dissolve readily in dilute groundwater and should be important contributors of solutes to groundwater, with potentially large amounts of evaporite mineral dissolution within the Mud Lake subbasin (Fig. 3). Silicate minerals dissolve slowly in groundwater, so the only silicate minerals likely to dissolve in significant quantities during the short residence time of shallow groundwater in the ESRP aquifer (based on average linear flow velocities and the approximate age of groundwater) are plagioclase and volcanic glass (Rattray and Ginsbach 
Table 2 Site number, analytical results for major ions (in $\mathrm{mg} / \mathrm{L}$ ), and charge balance (CB) of water samples

\begin{tabular}{|c|c|c|c|c|c|c|c|c|c|c|}
\hline Site No. & $\mathrm{Ca}$ & $\mathrm{Mg}$ & $\mathrm{Na}$ & $\mathrm{K}$ & $\mathrm{SiO}_{2}$ & $\mathrm{HCO}_{3}^{\mathrm{a}}$ & $\mathrm{Cl}$ & $\mathrm{SO}_{4}$ & $\mathrm{~F}$ & $\mathrm{CB}^{\mathrm{b}}(\%)$ \\
\hline 1 & 70 & 13.5 & 14.9 & 3.2 & 28 & 137 & 17.8 & 65.4 & 0.36 & 2.0 \\
\hline 2 & 32 & 9.5 & 14.5 & 2.7 & 37 & 140 & 7.7 & 14.0 & 0.89 & -0.7 \\
\hline 3 & 28 & 19.0 & 16.0 & 1.1 & 13 & 193 & 4.0 & 16.0 & 0.08 & -0.1 \\
\hline 4 & 26 & 10.9 & 10.3 & 2.0 & 36 & 142 & 6.6 & 5.3 & 0.29 & -0.2 \\
\hline 5 & 30 & 10.3 & 10.8 & 2.7 & 34 & 131 & 15.0 & 12.7 & 0.25 & -1.3 \\
\hline 6 & 30 & 8.3 & 9.0 & 2.4 & 34 & 131 & 5.6 & 9.3 & 0.49 & -2.0 \\
\hline 7 & 39 & 13.2 & 14.2 & 2.6 & 33 & 168 & 12.9 & 13.6 & 0.37 & 0.5 \\
\hline 8 & 62 & 13.7 & 11.0 & 2.9 & 30 & 252 & 6.0 & 10.4 & 0.32 & 0.5 \\
\hline 9 & 41 & 11.8 & 14.9 & 2.7 & 34 & 181 & 12.3 & 13.8 & 0.48 & -1.3 \\
\hline 10 & 30 & 9.5 & 11.5 & 2.2 & 35 & 140 & 9.6 & 6.0 & 0.41 & -0.1 \\
\hline 11 & 74 & 17.8 & 47.5 & 4.2 & 25 & 374 & 13.6 & 21.2 & 0.22 & -0.7 \\
\hline 12 & 32 & 9.6 & 13.2 & 2.9 & 34 & 162 & 9.5 & 9.1 & 0.41 & -3.9 \\
\hline 13 & 32 & 9.3 & 14.8 & 2.9 & 37 & 148 & 8.8 & 11.7 & 1.01 & -1.5 \\
\hline 14 & 49 & 13.8 & 11.2 & 2.7 & 28 & 176 & 25.8 & 17.2 & 0.26 & -0.7 \\
\hline 15 & 28 & 9.6 & 17.6 & 3.1 & 34 & 137 & 12.6 & 10.9 & 0.54 & 1.0 \\
\hline 16 & 55 & 15.1 & 15.4 & 2.8 & 29 & 219 & 11.4 & 27.1 & 0.36 & 0.6 \\
\hline 17 & 37 & 11.7 & 14.7 & 3.8 & 46 & 140 & 25.7 & 16.1 & 0.53 & 0.4 \\
\hline 18 & 28 & 8.6 & 11.9 & 2.8 & 35 & 131 & 9.8 & 8.9 & 0.45 & -1.3 \\
\hline 19 & 69 & 28.6 & 38.2 & 5.8 & 32 & 272 & 55.0 & 42.1 & 0.19 & 1.1 \\
\hline 20 & 58 & 19.9 & 30.8 & 5.5 & 32 & 307 & 19.2 & 16.1 & 0.27 & -0.6 \\
\hline 21 & 73 & 19.9 & 12.8 & 3.3 & 27 & 258 & 15.2 & 42.0 & 0.33 & 1.3 \\
\hline 22 & 66 & 23.0 & 45.0 & 5.4 & 28 & 327 & 51.0 & 39.0 & 0.30 & -5.3 \\
\hline 23 & 42 & 14.0 & 56.0 & 6.5 & 29 & 218 & 43.0 & 30.0 & 0.40 & 0.2 \\
\hline 24 & 109 & 33.0 & 47.3 & 5.4 & 34 & 322 & 93.0 & 91.3 & 0.16 & 0.9 \\
\hline 25 & 22 & 4.6 & 28.0 & 4.8 & 48 & 151 & 6.8 & 8.3 & 0.90 & -2.4 \\
\hline 26 & 65 & 16.1 & 12.7 & 3.5 & 35 & 237 & 16.2 & 36.9 & 0.36 & -0.7 \\
\hline 27 & 15 & 6.3 & 37.2 & 6.8 & 33 & 140 & 12.7 & 17.2 & 0.64 & -0.3 \\
\hline 28 & 67 & 16.7 & 15.7 & 4.1 & 37 & 198 & 47.5 & 39.5 & 0.25 & -0.8 \\
\hline 29 & 19 & 17.0 & 23.0 & 4.3 & 29 & 179 & 10.0 & 9.8 & 0.50 & -2.4 \\
\hline 30 & 75 & 26.7 & 85.0 & 7.2 & 27 & 457 & 36.1 & 29.3 & 0.15 & -0.6 \\
\hline 31 & 75 & 20.7 & 51.6 & 4.8 & 37 & 291 & 46.2 & 52.8 & 0.22 & 1.3 \\
\hline 32 & 75 & 19.9 & 11.1 & 2.9 & 27 & 258 & 7.4 & 51.8 & 0.41 & 2.2 \\
\hline 33 & 89 & 29.9 & 28.4 & 5.4 & 36 & 194 & 121 & 64.1 & 0.28 & -0.2 \\
\hline 34 & 41 & 14.6 & 25.8 & 3.4 & 39 & 180 & 16.4 & 48.1 & 0.47 & -1.6 \\
\hline 35 & 54 & 18.1 & 5.8 & 1.2 & 12 & 201 & 5.4 & 34.9 & 0.54 & 1.9 \\
\hline 55 & 47 & 7.7 & 11.4 & 2.9 & 29 & 164 & 15.8 & 15.9 & 0.43 & -1.0 \\
\hline 56 & 57 & 15.6 & 3.3 & 0.7 & 8 & 240 & 1.8 & 7.4 & 0.12 & 0.5 \\
\hline 57 & 87 & 16.0 & 26.4 & 13.6 & 34 & 168 & 6.7 & 191 & 7.0 & -1.6 \\
\hline 58 & 53 & 19.7 & 9.9 & 2.9 & 17 & 198 & 5.2 & 58.0 & 0.94 & 0.6 \\
\hline 59 & 39 & 8.9 & 3.2 & 0.7 & 8 & 149 & 3.4 & 9.3 & 0.10 & 0.1 \\
\hline 78 & 19 & 4.7 & 3.6 & 2.0 & 18 & 91 & 1.0 & 1.4 & 0.11 & -1.2 \\
\hline 79 & 59 & 18.0 & 8.9 & 2.2 & 15 & 306 & 8.4 & 51.0 & 0.30 & -14.4 \\
\hline 99 & 47 & 13.0 & 16.0 & 3.6 & 26 & 212 & 11.0 & 8.9 & 0.50 & 3.1 \\
\hline 100 & 7.3 & 0.5 & 390 & 7.5 & 47 & 900 & 12 & 99 & 13 & -0.83 \\
\hline
\end{tabular}

2014). Increasing potassium concentrations with decreasing depth in geothermal water below the ESRP aquifer (Mann 1986) indicate that upward-moving geothermal water may dissolve potassium feldspar in rhyolite. Incongruent dissolution of silicate minerals produces clay minerals; a calcium-sodium aluminosilicate stability diagram (with typical aluminum and silica activities for groundwater in the study area) indicates that the stable clay mineral in 
Table 3 Site number and analytical results for nitrogen species (in $\mathrm{mg} / \mathrm{L}$ as $\mathrm{N}$ ) and selected trace elements (in $\mu \mathrm{g} / \mathrm{L}$ )
Report site numbers $1-35$ wells, 55-59 springs, 78-79 streams, 99 lake, 100 geothermal well, $n a$ not analyzed, $E$ result estimated by laboratory

\begin{tabular}{|c|c|c|c|c|c|c|c|c|c|c|}
\hline Site no. & $\mathrm{NO}_{3}+\mathrm{NO}_{2}$ & $\mathrm{NO}_{2}$ & $\mathrm{NH}_{3}$ & $\mathrm{Al}$ & $\mathrm{Ba}$ & B & $\mathrm{Fe}$ & $\mathrm{Li}$ & $\mathrm{Mn}$ & $\mathrm{Sr}$ \\
\hline 1 & 13.2 & E0.001 & $<0.02$ & na & na & na & $<6$ & na & $<0.2$ & na \\
\hline 2 & 3.22 & $<0.002$ & $<0.02$ & na & 10 & na & $<6$ & na & E0.2 & na \\
\hline 3 & $<0.02$ & $<0.001$ & 0.03 & 1.8 & 85 & 14 & 635 & 17 & 27 & 1,721 \\
\hline 4 & 0.67 & $<0.002$ & $<0.02$ & na & na & na & $<8$ & na & $<0.4$ & na \\
\hline 5 & 0.74 & $<0.001$ & $<0.01$ & 2.7 & 26 & 25 & $<3.2$ & 7 & 1.6 & 131 \\
\hline 6 & 1.73 & $<0.001$ & $<0.01$ & 10.2 & 21 & 19 & 5.0 & 12 & $<0.1$ & 100 \\
\hline 7 & 3.25 & E0.001 & $<0.02$ & na & na & na & E5.5 & na & $<0.2$ & na \\
\hline 8 & 1.74 & $<0.001$ & $<0.01$ & na & na & na & $<3.2$ & na & $<0.2$ & na \\
\hline 9 & 2.14 & $<0.001$ & $<0.01$ & na & na & na & $<3.2$ & na & $<0.2$ & na \\
\hline 10 & 1.09 & $<0.001$ & 0.01 & na & na & na & $<3.2$ & na & $<0.2$ & na \\
\hline 11 & 4.88 & $<0.002$ & $<0.02$ & na & na & na & $<6$ & na & $<0.2$ & na \\
\hline 12 & 0.95 & $<0.001$ & $<0.01$ & $<1.7$ & 30 & 21 & 3.6 & 13 & $<0.1$ & 127 \\
\hline 13 & 2.52 & $<0.002$ & $<0.02$ & na & na & na & E5.7 & na & $<0.4$ & na \\
\hline 14 & 1.48 & $<0.001$ & $<0.01$ & na & na & na & $<3.2$ & na & $<0.2$ & na \\
\hline 15 & 1.21 & $<0.002$ & $<0.02$ & na & 29 & na & $<6$ & na & E0.1 & na \\
\hline 16 & 1.12 & $<0.002$ & $<0.02$ & na & na & na & $<8$ & na & $<0.4$ & na \\
\hline 17 & 1.34 & $<0.001$ & $<0.01$ & $<2.2$ & 56 & 117 & 3.3 & 6 & 0.2 & 400 \\
\hline 18 & 1.49 & E0.001 & 0.18 & na & na & na & E3.4 & na & 1.5 & na \\
\hline 19 & 5.30 & na & na & 2.0 & 151 & 36 & 73 & 14 & na & 306 \\
\hline 20 & 1.30 & $<0.001$ & $<0.01$ & na & na & na & $<3.2$ & na & $<0.2$ & na \\
\hline 21 & 1.76 & E0.002 & 0.03 & na & na & na & $<8$ & na & 1.0 & na \\
\hline 22 & 4.40 & $<0.01$ & $<0.01$ & $<10$ & 130 & 48 & 41 & 25 & 0.1 & 280 \\
\hline 23 & 4.10 & $<0.01$ & 0.01 & na & 95 & 50 & 5.0 & 32 & na & 180 \\
\hline 24 & 2.92 & $<0.001$ & $<0.01$ & $<2.2$ & 127 & 90 & 5.2 & 16 & 0.2 & 502 \\
\hline 25 & $<0.05$ & $<0.01$ & 0.20 & $<10$ & 62 & 84 & 85 & 71 & 91 & 77 \\
\hline 26 & 1.51 & $<0.002$ & E0.01 & na & 112 & na & $<6$ & na & $<0.6$ & na \\
\hline 27 & 0.11 & 0.004 & 0.14 & na & na & na & E4.8 & na & 5.7 & na \\
\hline 28 & 1.71 & $<0.002$ & $<0.01$ & na & 74 & na & $<6$ & na & $<0.6$ & na \\
\hline 29 & $<0.05$ & 0.020 & 0.33 & 10 & 51 & na & 11 & 47 & na & 160 \\
\hline 30 & 8.52 & $<0.001$ & $<0.01$ & $<2.2$ & 138 & 78 & 5.4 & 28 & 0.3 & 329 \\
\hline 31 & 4.43 & $<0.001$ & $<0.01$ & $<2.2$ & 78 & 82 & 4.7 & 20 & $<0.1$ & 308 \\
\hline 32 & 0.54 & $<0.001$ & $<0.01$ & $<2.2$ & 56 & 26 & $<3.2$ & 5 & $<0.1$ & 417 \\
\hline 33 & 4.20 & $<0.002$ & $<0.02$ & na & na & na & $<6$ & na & $<0.2$ & na \\
\hline 34 & 1.27 & $<0.002$ & E0.01 & na & 51 & na & 16.1 & na & E0.5 & na \\
\hline 35 & 0.22 & $<0.001$ & $<0.01$ & $<2.2$ & 64 & 18 & $<3.2$ & 5 & 0.1 & 317 \\
\hline 55 & 0.88 & $<0.001$ & $<0.01$ & $<2.2$ & 87 & 25 & 13.8 & 10 & $<0.1$ & 146 \\
\hline 56 & 0.43 & $<0.001$ & $<0.01$ & $<2.2$ & 83 & 8 & $<3.2$ & 4 & $<0.1$ & 122 \\
\hline 57 & $<0.05$ & $<0.006$ & 0.11 & E14 & 45 & 90 & 20 & 48 & 13 & 1,000 \\
\hline 58 & 0.14 & $<0.001$ & $<0.01$ & $<2.2$ & 70 & 35 & $<3.2$ & 15 & 0.2 & 337 \\
\hline 59 & 0.70 & $<0.001$ & $<0.01$ & $<2.2$ & 143 & 8 & $<3.2$ & 1 & $<0.1$ & 61 \\
\hline 78 & $<0.02$ & $<0.001$ & 0.02 & 13.9 & 33 & 8 & 31.4 & 3 & 2.3 & 77 \\
\hline 79 & 0.18 & na & na & na & na & na & na & na & na & 310 \\
\hline 99 & 0.25 & na & na & na & na & na & 20 & na & 80 & 170 \\
\hline 100 & na & na & na & na & na & 560 & 1,100 & na & 50 & 150 \\
\hline
\end{tabular}

contact with groundwater is calcium montmorillonite (Fig. 8). Redox reactions may include oxidation of organic matter in wetlands and reduced species in geothermal water; $\delta^{15} \mathrm{~N}$ values of 6.9 and $9.5 \%$ for sites 25 and 29 (Knobel et al. 1999), respectively, indicate that denitrification was not an important process in these anoxic waters. Clay is an efficient cation exchange substrate, so cation exchange may be important in areas where surface water infiltrates through 
Table 4 Site number, date sampled, measurements of the stable isotopes ( 2 sigma uncertainty) of hydrogen, oxygen, and carbon and the radiogenic isotope tritium (1 sigma uncertainty), and approximate age of water

\begin{tabular}{|c|c|c|c|c|c|c|}
\hline \multirow[t]{2}{*}{ Site no. } & \multirow[t]{2}{*}{ Date sampled } & \multicolumn{3}{|l|}{ Stable isotopes $(\%)$} & \multicolumn{2}{|l|}{ Tritium } \\
\hline & & Hydrogen $\left(\delta^{2} \mathrm{H} \pm 2\right)$ & Oxygen $\left(\delta^{18} \mathrm{O} \pm 0.2\right)$ & Carbon $\left(\delta^{13} \mathrm{C} \pm 0.2\right)$ & $(\mathrm{pCi} / \mathrm{L})$ & Approximate age of water \\
\hline 3 & $8 / 8 / 2011$ & -131.8 & -17.48 & -10.35 & $-0.5 \pm 1.9$ & pre-1952 \\
\hline 5 & $8 / 9 / 2011$ & -131.5 & -17.33 & -11.21 & $-4 \pm 2.3$ & pre-1952 \\
\hline 6 & $8 / 8 / 2011$ & -132.9 & -17.62 & -13.41 & $13.3 \pm 2.1$ & mixture \\
\hline 9 & $8 / 29 / 1989$ & -133 & -17.45 & na & na & na \\
\hline 12 & $8 / 9 / 2011$ & -134.4 & -17.62 & -13.21 & $8.6 \pm 1.9$ & mixture \\
\hline 17 & $6 / 4 / 2012$ & -134.1 & -17.35 & -11.42 & $-0.1 \pm 2.1$ & pre-1952 \\
\hline 19 & $5 / 14 / 1997$ & -120.8 & -14.88 & -12.7 & $53.5 \pm 1.9$ & post-1952 \\
\hline 22 & 6/4/1991 & -120 & -14.95 & -13.2 & $96 \pm 13$ & post-1952 \\
\hline 23 & $8 / 29 / 1989$ & -123 & -15.55 & na & na & na \\
\hline 24 & $6 / 6 / 2012$ & -132.3 & -17.26 & -13.14 & $9.7 \pm 2.2$ & mixture \\
\hline 25 & $6 / 11 / 1991$ & -135 & -17.90 & -12.6 & $2.3 \pm 1.3^{\mathrm{a}}$ & pre-1952 \\
\hline 29 & $6 / 12 / 1991$ & -135 & -17.85 & -11.7 & $-22 \pm 13$ & pre-1952 \\
\hline 30 & $6 / 6 / 2012$ & -130.9 & -16.98 & -15 & $9.7 \pm 2.2$ & mixture \\
\hline 31 & $6 / 6 / 2012$ & -132.4 & -17.13 & -12.28 & $4.7 \pm 2.1$ & mixture \\
\hline 32 & $6 / 4 / 2012$ & -137.9 & -18.00 & -11.63 & $19.3 \pm 2.3$ & mixture \\
\hline 35 & $6 / 4 / 2012$ & -143.3 & -18.66 & -8.18 & $8.5 \pm 2.3$ & mixture \\
\hline 55 & $6 / 5 / 2012$ & -137.7 & -18.03 & -9.47 & $10.5 \pm 2.2$ & mixture \\
\hline 56 & $6 / 5 / 2012$ & -131.4 & -17.41 & -12.72 & $28.8 \pm 2.3$ & post-1952 \\
\hline 57 & $11 / 5 / 1990$ & -135 & -18.10 & -3.9 & $0.4 \pm 0.3$ & pre-1952 \\
\hline 58 & $6 / 5 / 2012$ & -135.0 & -17.65 & -5.55 & $3.1 \pm 2.1$ & mixture \\
\hline 59 & $6 / 5 / 2012$ & -129.2 & -17.02 & -9.12 & $33.1 \pm 2.5$ & post- 1952 \\
\hline 78 & 8/8/2011 & -124.7 & -16.24 & -7.98 & $26.6 \pm 2.1$ & post-1952 \\
\hline 99 & $3 / 28 / 1991$ & -132 & -17.75 & na & na & na \\
\hline 99 & $5 / 2 / 1991$ & -133 & -17.60 & na & na & na \\
\hline 99 & $5 / 31 / 1991$ & -134 & -17.85 & na & na & na \\
\hline 99 & $7 / 2 / 1991$ & -131 & -17.75 & na & na & na \\
\hline 99 & $7 / 30 / 1991$ & -133 & -17.70 & na & na & na \\
\hline 99 & $8 / 29 / 1991$ & -134 & -17.85 & na & na & na \\
\hline 99 & $10 / 2 / 1991$ & -135 & -17.75 & na & na & na \\
\hline 99 & $11 / 4 / 1991$ & -133 & -17.30 & na & na & na \\
\hline 99 & $12 / 6 / 1991$ & -129 & -16.70 & na & na & na \\
\hline 99 & $1 / 3 / 1992$ & -130 & -16.90 & na & na & na \\
\hline 99 & 2/7/1992 & -135 & -17.50 & na & na & na \\
\hline 99 & $3 / 6 / 1992$ & -122 & -15.55 & na & na & na \\
\hline 99 & 4/6/1992 & -133 & -17.60 & na & na & na \\
\hline 99 & $4 / 30 / 1992$ & -135 & -17.70 & na & na & na \\
\hline 99 & $6 / 18 / 1992$ & -134 & -17.80 & na & na & na \\
\hline 99 & 10/29/1997 & -132 & -17.32 & na & na & na \\
\hline
\end{tabular}

Report site numbers 3-35 wells, 55-59 springs, 78 stream, 99 lake, na not analyzed

a Tritium sample collected on 5/21/1997

sediment. For dilute surface water with much larger concentrations of calcium than magnesium, such as water from Camas Creek (site 78, Table 2), calcium should replace sodium on exchange sites (Drever 1997).

\section{Geochemical modeling}

Geochemical modeling attempts to identify the net chemical reactions that account for observed changes in chemistry 
Fig. 5 Map showing surface geology (Lewis et al. 2012) and spatial distribution of concentrations (in $\mathrm{mmol} / \mathrm{L}$ ) of selected major ions in water

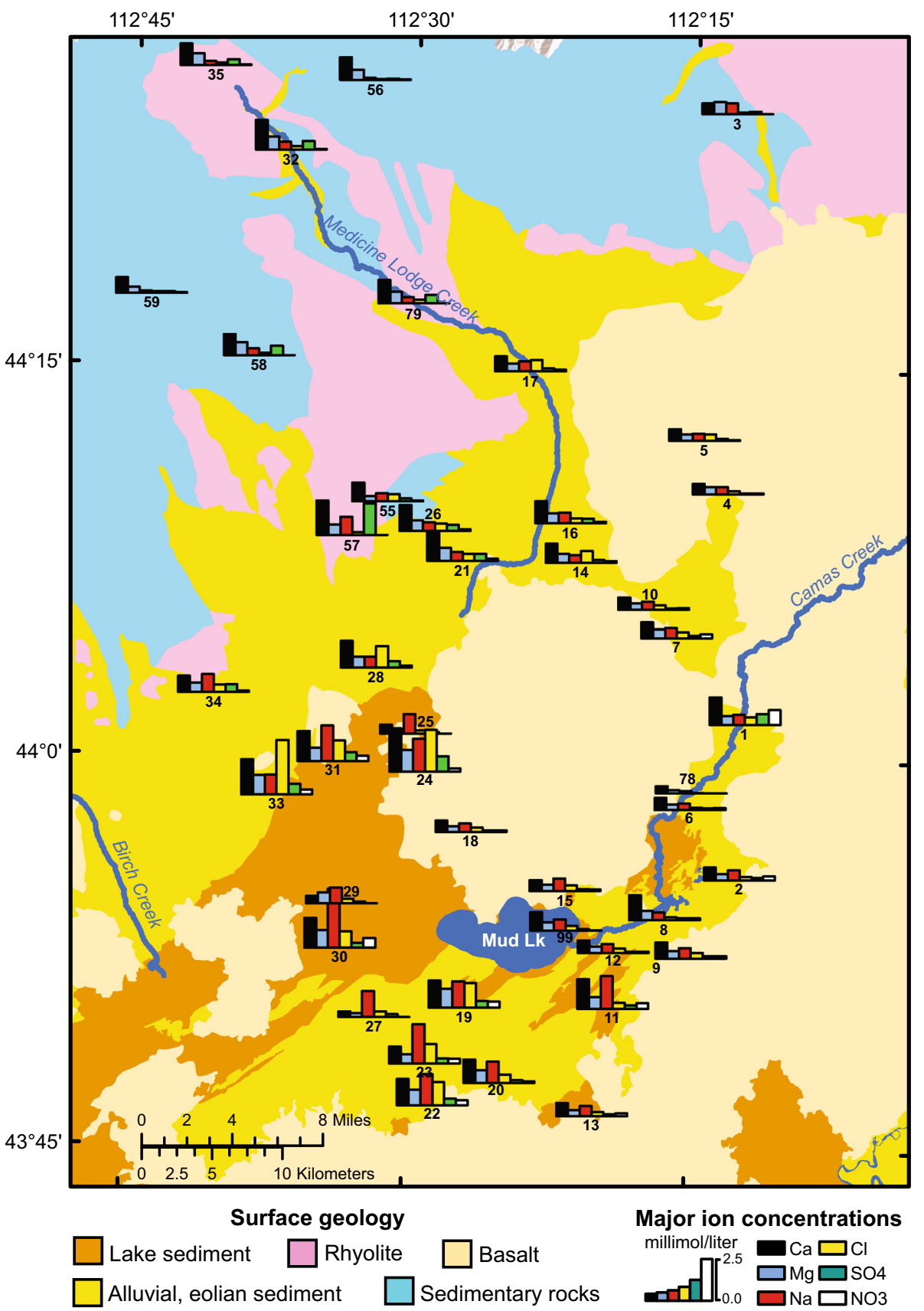

between initial (one or more) and final (one) water compositions (solutions) along a single flowline or joined (mixture) flowlines. Modeling was performed with PHREEQC using the minimal mode, which means that models were reduced to the minimum number of phases needed to satisfy model constraints (Parkhurst and Appelo 2013). Solutions used in the models were the water compositions in Tables 1, 2, and 3. Water from Camas Creek was used to represent relatively unevaporated Mud Lake water because the water from Mud Lake collected for chemical analyses in Tables 1, 2, and 3 was significantly evaporated. Solution uncertainties were the larger of the $\mathrm{CB}$ (absolute value) of a solution (rounded up to the nearest $1 \%$ ) or $5 \%$. Where measurements of aluminum and iron were not available, these constituents were assigned values of $<10$ and $<20 \mu \mathrm{g} / \mathrm{L}$, respectively. Values reported (or assigned) as "less than" were modeled as one-half the "less than" value with an uncertainty of $100 \%$. All solutions were assigned a pe of 4 except for the deep geothermal groundwater from site 100 . Site 100 was assigned a pe of -5 so that speciation of constituents with PHREEQC would produce reduced species of carbon (methane) and sulfur (hydrogen sulfide). 
Fig. 6 Major-ion composition of water
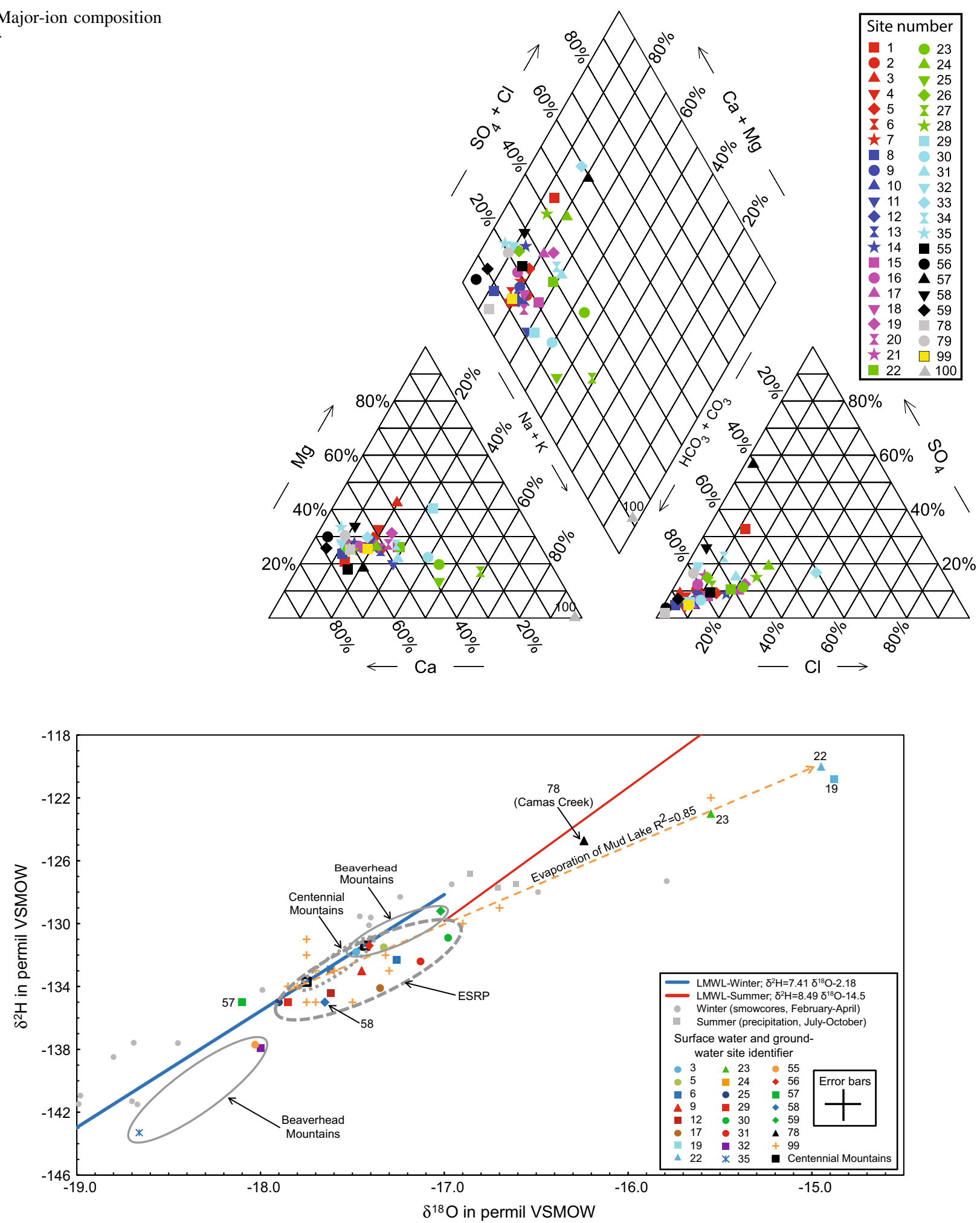

Fig. 7 Stable isotope ratios of hydrogen and oxygen and local meteoric water lines (LMWL) for winter and summer (winter snowcore, summer precipitation, and LMWL from Benjamin et al.
2004; Centennial Mountains data from Rattray and Ginsbach 2014). VSMOW, Vienna Standard Mean Ocean Water 
Table 5 Estimated age of water based on tritium concentrations in water samples

\begin{tabular}{lll}
\hline Approximate age of water & \multicolumn{2}{l}{ Tritium concentration $(\mathrm{pCi} / \mathrm{L})$} \\
\cline { 2 - 3 } & \multicolumn{1}{l}{ Year } \\
\cline { 2 - 3 } & 1991 & 2012 \\
\hline Pre-1952 (old, pre bomb) & $<4$ & $<1$ \\
Post-1952 (young, post bomb) & $>60$ & $>20$ \\
Mixture & $4-60$ & $1-20$ \\
\hline
\end{tabular}

Elements included in the models were hydrogen, oxygen, carbon, silica, nitrogen, sulfur, chloride, fluoride, calcium, magnesium, sodium, potassium, aluminum, and iron. Phases included carbonates (calcite, dolomite), evaporites (gypsum, halite, sylvite, bischofite), silicates [rhyolitic volcanic glass, plagioclase $\left(\mathrm{An}_{25}\right.$ and $\left.\mathrm{An}_{60}\right)$, potassium feldspar], fluorite, calcium montmorillonite, goethite, fertilizer (ammonium nitrate, sylvite), road salt (halite), anti-icing liquid $\left(\mathrm{MgCl}_{2}\right.$, represented as bischofite), organic matter, and gasses (methane, hydrogen sulfide, $\mathrm{DO}, \mathrm{CO}_{2}$ ). DO was included as a phase because the water sample from Camas Creek (site 78) had a temperature of $19.3{ }^{\circ} \mathrm{C}$ and was undersaturated with DO; however, most water from Camas Creek would recharge at colder temperatures and be saturated with DO. Based on saturation indices, kinetic considerations, and redox conditions, all phases should dissolve in groundwater except for calcium montmorillonite and goethite (precipitate) and calcite (dissolve or precipitate).

Geochemical models were run with water compositions from sites 6-31 and 33-34 as final solutions. From one to many plausible results (i.e., model results that were consistent with land cover, hydrology, geochemistry, and saturation indices) were produced for each site except for site 17 (the results for site 17 were not consistent with $\delta^{2} \mathrm{H}$, $\delta^{18} \mathrm{O}$, and tritium values). Plausible model results from individual sites were similar in overall mass transfers of carbonates, silicates, evaporites, etc., but differed as to which specific phases were involved in mass transfers. A representative model result for each site is shown in Table 6 (small amounts of fluoride dissolved and goethite precipitated in nearly all models but are not shown in Table 6).

The model results indicate that sources of water to the ESRP aquifer were groundwater from the Beaverhead Mountains and the Camas Creek drainage basin; infiltration of surface water from Medicine Lodge Creek, Camas Creek, Mud Lake, and irrigation water; and upward flow of geothermal water. Because Camas Creek was the primary source of surface water to Mud Lake and for most surface water used for irrigation, and because surface water recharge occurred over most of the ESRP aquifer, Camas

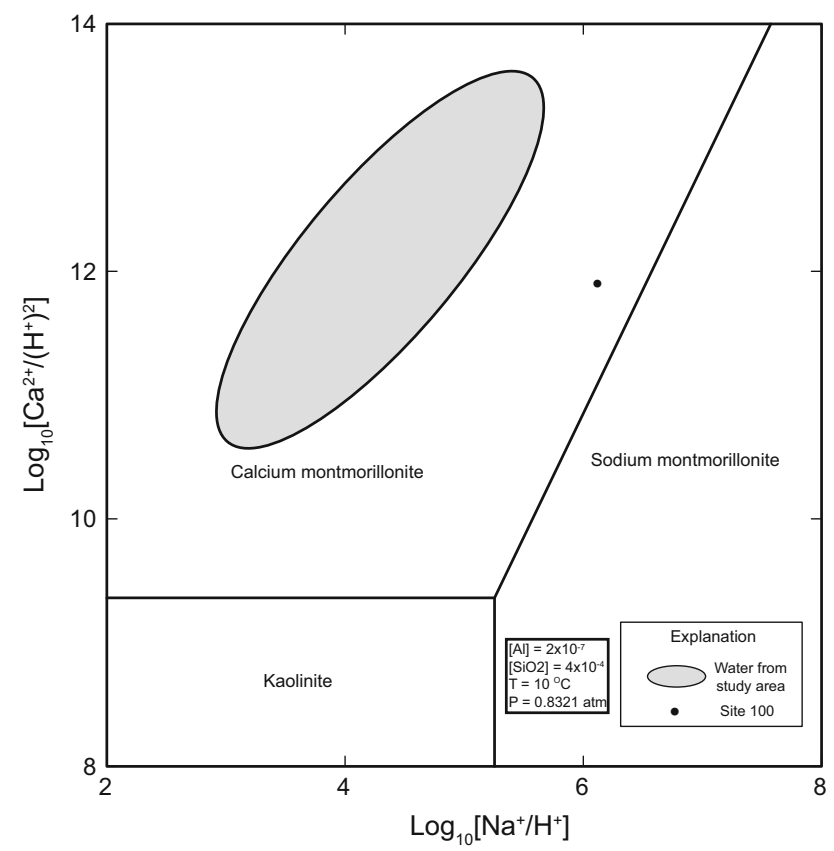

Fig. 8 Stability relations among kaolinite, calcium montmorillonite, and sodium montmorillonite with compositions of water samples indicated. Brackets indicate thermodynamic activity of indicated species

Creek was a very important source of recharge to the aquifer.

Mixing of groundwater with surface water or other groundwater occurred throughout the ESRP, and mixing of groundwater with surface water, other groundwater, and geothermal water was modeled for four sites (sites 25, 27, 29 , and 34) located in volcanic vent corridors. Evaporation was modeled to reproduce the chemistry of groundwater from sites downgradient of the CNWR (site 8) and Mud Lake (sites 19 and 22).

Carbonate reactions, silicate weathering, and dissolution of evaporites and fertilizer explain most of the change in chemistry in the ESRP aquifer (Table 6). Large amounts of gypsum and halite dissolution support the interpretation that evaporite deposits are present within the Mud Lake subbasin and are a significant source of chloride, sodium, sulfate, and calcium in groundwater. Redox reactions were important at the CNWR and Mud Lake (from oxidation of organic matter) and at locations (sites 25, 27, 29, and 34) where upwelling geothermal water mixed with groundwater (from oxidation of reduced carbon and sulfur species in the geothermal water). For example, anoxic groundwater at two sites (sites 25 and 29) was modeled by mixing geothermal water (site 100 ) with surface water and groundwater upgradient of these sites and oxidation of reduced species in the geothermal water. The groundwater would only be anoxic at these sites if the groundwater was relatively stagnant because a continual inflow of oxidized groundwater would produce oxidized 


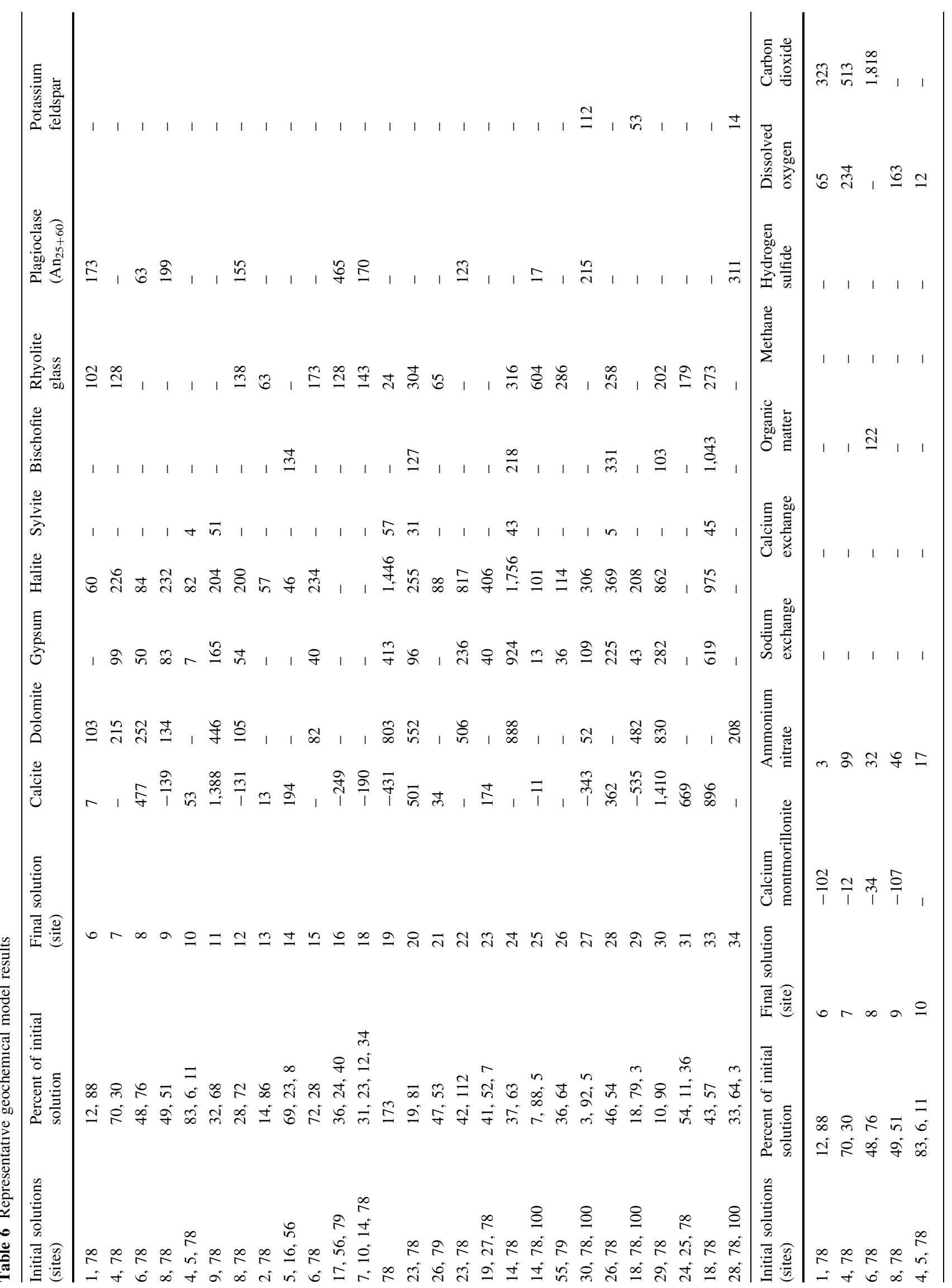




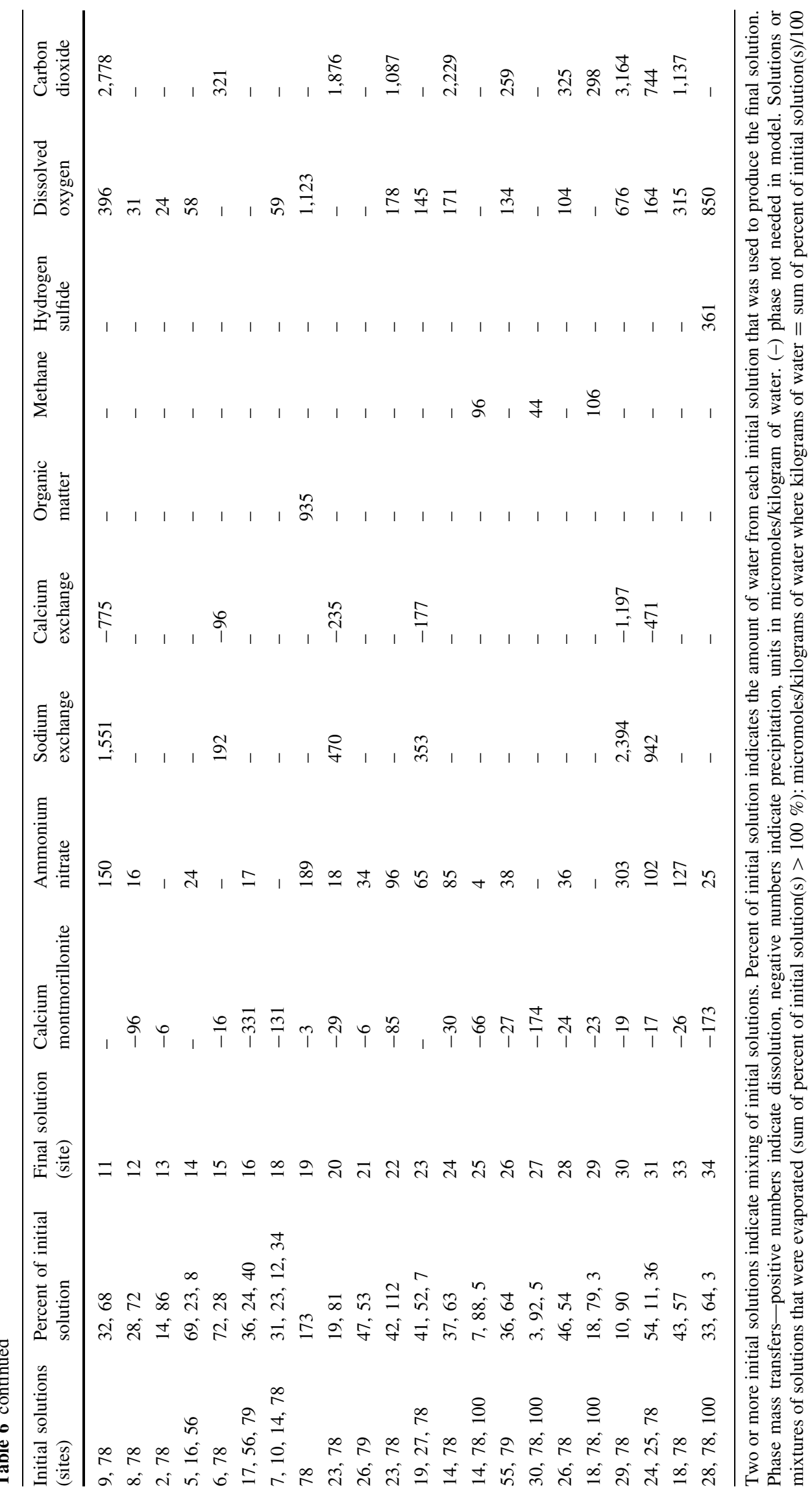


Fig. 9 Specific conductance versus concentrations of nitrate plus nitrite in groundwater from areas within and outside surficial lake sediment on the ESRP in the Mud Lake area and within the area of surficial lake sediment at the Idaho National Laboratory (Figs. 1, 3).

Trendline and correlation coefficient shown for groundwater from within the area of lake sediment in the Mud Lake area

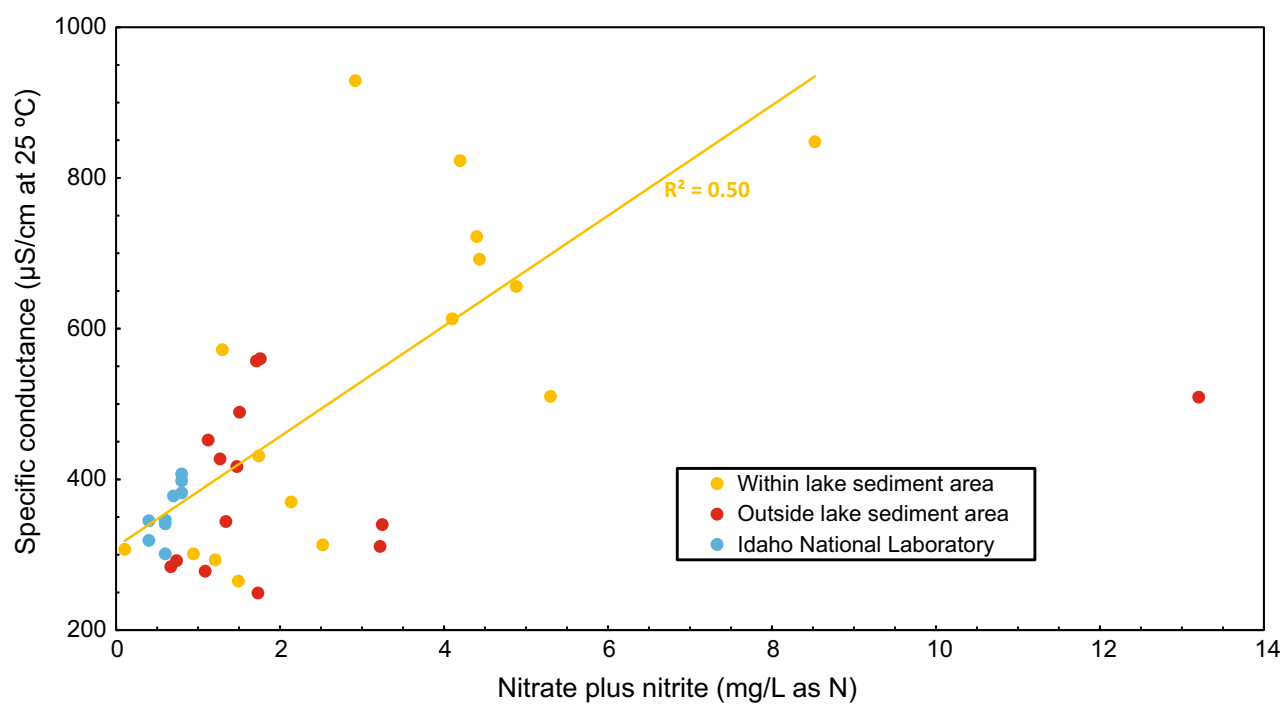

conditions. Cation exchange was locally important in areas where water had significant contact with sediment, for instance, areas where surface water infiltration occurred through wetlands or from irrigation.

Bischofite (could also be carnallite or anti-icing liquid) appears to be a source of chloride in a few locations. At one location (site 33), a large mass transfer of bischofite into solution was required (Table 6 ) because water from this site had an unusually large chloride/sodium ratio (4.3, Table 2). A similar chloride/sodium ratio, 4.1, was observed at site 22 in 1950 (Olmstead 1962); however, since 1950, the SpC at site $22\left(1,000 \mu \mathrm{S} / \mathrm{cm}\right.$ at $25^{\circ} \mathrm{C}$ in 1950; Olmstead 1962) decreased $28 \%$ and the chloride/sodium ratio decreased to 1.1 (Table 2). The $\mathrm{SpC}$ at site 33 decreased $25 \%$ since measurements were first made in 2002 (U.S. Geological Survey 2014), although the chloride/sodium ratio has remained stable. A possible explanation for the initial large $\mathrm{SpC}$ and chloride/sodium ratio at these sites followed by a decreasing $\mathrm{SpC}$ and ratio (at site 22) is dissolution of evaporite minerals, including evaporite minerals that precipitated from a magnesium chloride brine. Magnesium chloride brines are present in some present-day salt lakes (Krupp 2005) and may have formed locally in the study area during the multiple climate-derived fluctuations of Lake Terreton.

\section{Location where dissolution of evaporite deposits is occurring}

Evaporite deposits within the Mud Lake area are associated with sediment of Lake Terreton. Surficial deposits of lake sediment extend over the southwestern part of the ESRP in the Mud Lake area and westward onto the INL (Figs. 1, 3).
Gypsum identified in lake sediment in several wells at depths ranging from 60 to $740 \mathrm{~m}$ below land surface (Blair 2001; Geslin et al. 2002) indicates that evaporite deposits may be present at various depths. To determine whether large amounts of evaporite deposits are dissolving within or outside areas defined by surficial lake sediment, or both, and in the unsaturated zone (from infiltration of irrigation water), saturated zone, or both, a plot was made of $\mathrm{SpC}$ versus $\mathrm{NO}_{3}+\mathrm{NO}_{2}$ in groundwater (where $\mathrm{SpC}$ is related to the dissolution of evaporite minerals and the concentration of $\mathrm{NO}_{3}+\mathrm{NO}_{2}$ is related to infiltration of irrigation water).

Groundwater was grouped by location-within and outside the area of surficial lake sediment on the ESRP in the Mud Lake area (excluding anoxic groundwater with input of thermal water that has anomalous chemistry and hydrology) and within the area of surficial lake sediment on the ESRP at the INL west of the Mud Lake area (Figs. 3, 9). The ESRP in the Mud Lake area is extensively irrigated, but no irrigation occurs on the INL (Figs. 1, 2, 3).

The range (and mean) of $\mathrm{SpC}$ in groundwater from areas within and outside surficial lake sediment in the Mud Lake area were 265-929 (540) and 249-560 (394) $\mu \mathrm{S} / \mathrm{cm}$ at $25^{\circ} \mathrm{C}$, respectively. The larger $\mathrm{SpC}$ in groundwater beneath surficial lake sediments in the Mud Lake area indicates that evaporite deposits are probably present in greater quantity beneath the area where surficial lake sediment is present than in areas where surficial lake sediment is not present. Groundwater from beneath surficial lake sediment in the Mud Lake area also shows a moderate positive correlation $\left(\mathrm{R}^{2}=0.50\right.$; Fig. 9) between $\mathrm{SpC}$ and $\mathrm{NO}_{3}+\mathrm{NO}_{2}$, indicating that infiltration of irrigation water is probably dissolving evaporite deposits in 
the unsaturated zone. The SpC (range 301-407 $\mu \mathrm{S} / \mathrm{cm}$ at $25{ }^{\circ} \mathrm{C}$, mean $=357 \mu \mathrm{S} / \mathrm{cm}$ at $25^{\circ} \mathrm{C}$ ) of groundwater beneath surficial lake sediment at the INL (Knobel et al. 1999), where no irrigation occurs, is smaller than the $\mathrm{SpC}$ of groundwater beneath surficial lake sediment in the Mud Lake area (Fig. 9). This result also supports the hypothesis that infiltration of irrigation water through the unsaturated zone is dissolving evaporite deposits associated with Lake Terreton resulting in elevated concentrations of some solutes in groundwater in the Mud Lake area.

\section{Conclusions}

The source of elevated solute concentrations in groundwater in the Mud Lake area is evaporite deposits in the unsaturated zone associated with Pleistocene Lake Terreton. Large amounts of chloride, sodium, sulfate, and calcium are added to groundwater from irrigation water infiltrating through lake bed sediments containing these evaporite deposits and the resultant dissolution of gypsum, halite, sylvite, and bischofite.

Acknowledgments This research was funded by the U.S. Department of Energy.

Open Access This article is distributed under the terms of the Creative Commons Attribution License which permits any use, distribution, and reproduction in any medium, provided the original author(s) and the source are credited.

\section{References}

Ackerman DJ, Rattray GW, Rousseau JP, Davis LC, Orr BR (2006) A conceptual model of ground-water flow in the eastern Snake River Plain aquifer at the Idaho National Laboratory and vicinity with implications for contaminant transport. U.S. Geological Survey Scientific Investigations Report 2006-5122

Anderson SR, Kuntz MA, Davis LC (1999) Geologic controls of hydraulic conductivity in the Snake River Plain aquifer at and near the Idaho National Engineering and Environmental Laboratory, Idaho. U.S. Geological Survey Water-Resources Investigations Report 99-4033

Benjamin L, Knobel LL, Hall LF, Cecil LD, Green JR (2004) Development of a local meteoric water line for southeastern Idaho, western Wyoming, and south-central Montana. U.S. Geological Survey Scientific Investigations Report 2004-5126

Blair JJ (2001) Sedimentology and stratigraphy of sediments of the Big Lost Trough subsurface from selected boreholes at the Idaho National Engineering and Environmental Laboratory, Idaho. Thesis, Idaho State University

Busenberg E, Plummer LN, Doughten MW, Widman PK, Bartholomay RC (2000) Chemical and isotopic composition of gas concentrations of ground water and surface water from selected sites at and near the Idaho National Engineering and Environmental Laboratory, Idaho, 1994-1997. U.S. Geological Survey Open-File Report 00-81
Busenberg E, Plummer LN, Bartholomay RC (2001) Estimated age and source of the young fraction of ground water at the Idaho National Engineering and Environmental Laboratory. U.S. Geological Survey Water-Resources Investigations Report 01-4265

Clark ID, Fritz P (1997) Environmental isotopes in hydrogeology. Lewis Publishers, Boca Raton

Drever JI (1997) The geochemistry of natural waters, 3rd edn. Prentice Hall, Upper Saddle River

Freeze RA, Cherry JA (1979) Groundwater. Prentice Hall, Englewood Cliffs

Garabedian SP (1992) Hydrology and digital simulation of the regional aquifer system, eastern Snake River Plain, Idaho. U.S. Geological Survey Professional Paper 1408-F

U.S. Geological Survey (2006) Collection of water samples (version 2.0, September 2006): U.S. Geological Survey Techniques of Water-Resources Investigations, book 9, chap. A4, http://pubs. er.usgs.gov/publication/twri09A4. Accessed 6 August 2013

U.S. Geological Survey (2007) 2001 national land cover data (2001 NLCD). http://www.epa.gov/mrlc/nlcd-2001.html. Accessed 6 August 2013

U.S. Geological Survey (2014) National Water Quality Information System database. http://waterdata.usgs.gov/nwis. Accessed 6 January 2014

Geslin JK, Link PK, Riesterer JW, Kuntz MA, Fanning CM (2002) Pliocene and Quaternary stratigraphic architecture and drainage systems of the Big Lost Trough, northeastern Snake River Plain, Idaho. In: Link PK, Mink LL (eds) Geology, Hydrogeology, and Environmental Remediation: Idaho National Engineering and Environmental Laboratory, Eastern Snake River Plain, Idaho, Geological Society of America Special Paper 353:11-26

Gianniny GL, Thackray GD, Kaufman DS, Forman SL, Sherbondy MK, Findeisen D (2002) Late Quaternary highstands in the Mud Lake and Big Lost Trough subbasins of Lake Terreton, Idaho. In: Link PK, Mink LL (eds) Geology, Hydrogeology, and Environmental Remediation: Idaho National Engineering and Environmental Laboratory, Eastern Snake River Plain, Idaho, Geological Society of America Special Paper 353:77-90

Ginsbach ML (2013) Geochemical evolution of groundwater in the Medicine Lodge Creek drainage basin, eastern Idaho. Thesis, Idaho State University

International Atomic Energy Agency (2013) Global network of isotopes in precipitation. http://wwwnaweb.iaea.org/napc/ih/ IHS_resources_gnip.html. Accessed August 132013

Knobel LL, Bartholomay RC, Tucker BJ, Williams LM, Cecil LD (1999) Chemical constituents in ground water from 39 selected sites with an evaluation of associated quality assurance data, Idaho National Engineering and Environmental Laboratory and vicinity, Idaho. U.S. Geological Survey Open-File Report 99-246

Knobel LL, Bartholomay RC, Rousseau JP (2005) Historical development of the U.S. Geological Survey hydrologic monitoring and investigative programs at the Idaho National Engineering and Environmental Laboratory,, Idaho, 1949 to 2001. U.S. Geological Survey Open-File Report 2005-1223

Krupp RE (2005) Formation and chemical evolution of magnesium chloride brines by evaporite dissolution processes-implications for evaporite geochemistry. Geochim Cosmochim Acta 69:4283-4299

Kuntz MA, Covington HR, Schorr LJ (1992) An overview of basaltic volcanism on the eastern Snake River Plain, Idaho. In: Link PK, Kuntz MA, Platt LB (eds) Regional geology of eastern Idaho and western Wyoming, vol 179. Geological Society of America Memoir, Boulder, pp 289-304

Kuntz MA, Skipp B, Lanphere MA, Scott WE, Pierce KL, Dalrymple GB, Champion DE, Embree GF, Page WR, Morgan LA, Smith RP, Hackett WR, Rodgers DW (1994) Geologic map of the 
Idaho National Engineering Laboratory and adjoining areas, eastern Idaho. U.S. Geological Survey Map I-2330

Lewis RS, Link PK, Stanford LR, Long SP (2012) Geologic Map of Idaho. Idaho Geological Survey Map 9 http://www.idahogeol ogy.org/Products/reverselook.asp?switch=title \&value=Geologic_ Map_of_Idaho. Accessed 3 Nov 2014

Lindholm GF (1996) Summary of the Snake River Plain regional aquifer-system analysis in Idaho and eastern Oregon. U.S. Geological Survey Professional Paper 1408-A

Mann LJ (1986) Hydraulic properties of rock units and chemical quality of water for INEL-1-A 10,365-foot deep test hole drilled at the Idaho National Engineering Laboratory, Idaho. U.S. Geological Survey Water-Resources Investigations Report 86-4020

Michel RL (1989) Tritium deposition in the continental United States. U.S. Geological Survey Water-Resources Investigations Report 89-4072

Morgan LA, Doherty DJ, Leeman WP (1984) Ignimbrites of the eastern Snake River Plain-evidence for major caldera-forming eruptions. J Geophys Res 89:8665-8678

Nace RL, Deutsch M, Voegeli PT (1956) Geography, geology, and water resources of the National Reactor Testing Station, IdahoPart 2. Geography and geology. U.S. Geological Survey OpenFile Report

Olmstead FH (1962) Chemical and physical character of ground water in the National Reactor Testing Station, Idaho. U.S. Atomic Energy Commission, Idaho Operations Office, Publication IDO22043-USGS

Parkhurst DL, Appelo CAJ (2013) Description of input and examples for PHREEQC Version $\overline{3} \mathrm{~A}$ computer program for speciation, batch reaction, one-dimensional transport, and inverse geochemical calculations. U.S. Geological Survey Techniques and Methods, book 6, chap. A43. http://pubs.usgs.gov/tm/06/a43/
Rattray GW (2014) Evaluation of quality-control data collected by the U.S. Geological Survey for routine water-quality activities at the Idaho National Laboratory and vicinity, southeastern Idaho, 2002-08. U.S. Geological Survey Scientific Investigations Report 2014-5027

Rattray GW, Ginsbach ML (2014) Geochemistry of the Beaver and Camas Creek drainage basins, eastern Idaho. U.S. Geological Survey Scientific Investigations Report 2014-5226

Robertson JB, Schoen R, Barraclough JT (1974) The influence of liquid waste disposal on the geochemistry of water at the National Reactor Testing Station, Idaho: 1952-1970. U.S. Geological Survey Open-File Report

Spinazola JM, Tungate AM, Rogers, TL (1992) Geohydrologic and chemical data from wells in the Mud Lake area, eastern Idaho, 1988-91. U.S. Geological Survey Open-File Report 92-133

Schramke JA, Murphy EM, Wood BD (1996) The use of geochemical mass-balance and mixing models to determine groundwater sources. Appl Geochem 11:523-539

Spinazola JM (1994) Geohydrology and simulation of flow and water levels in the aquifer system in the Mud Lake area of the eastern Snake River Plain, eastern Idaho. U.S. Geological Survey WaterResources Investigations Report 93-4227

Stearns HT, Bryan LL, Crandall L (1939) Geology and water resources of the Mud Lake region, Idaho. U.S. Geological Survey Water-Supply Paper 818

U.S. Department of Agriculture Natural Resources Conservation Service soil survey staff (2014) Web soil survey. http:// websoilsurvey.nrcs.usda.gov/. Accessed 3 November 2014

Wood WW, Low WH (1988) Solute geochemistry of the Snake River Plain aquifer system, Idaho and eastern Oregon. U.S. Geological Survey Professional Paper 1408-D 